\title{
Regulatory Safeguards in Mega-regionals against Sovereignty Loss
}

\author{
Christian Riffel
}

\begin{abstract}
Trade and investment agreements are disputed because they limit the regulatory autonomy of national legislatures of participating countries. This is particularly true of mega-regionals given their expanded scope. On that account, negotiators build safeguards into the agreements with a view to containing the intrusion into the national legal order. The debate revolves around whether the envisaged safeguards are sufficient to achieve that goal or whether, de lege ferenda, more needs to be done to find the right power balance. The present essay, first of all, elucidates the extent of sovereignty loss as a result of mega-regionals, and secondly, explores some options to secure policy space for national lawmakers, such as the use of broader exception clauses or the setting of guidelines for the calculation of damages.
\end{abstract}

\section{Keywords}

Mega-Regionals; Sovereignty; Regulatory Autonomy; Direct Effect; ISDS; Right to Regulate; Exceptions; Loss of Profits

\section{Introduction}

Mega-regionals are about to become the most significant building blocks of the world economic order. Many constituencies are concerned, however, that national sovereignty is sold out through the back door by their governments concluding treaties like the Trans-Pacific Partnership (TPP) or the Comprehensive Economic and Trade Agreement (CETA). The protection of foreign investments therein and, in particular, the provision of investor-State dispute settlement (ISDS) mechanisms came to the fore. ${ }^{1}$ An ISDS clause gives foreign investors, i.e. private entities, legal standing before international tribunals. In other words, they can challenge the way they are treated by host States. As a result, those tribunals have the power to review the legality of acts of a host State, including acts of parliament. ${ }^{2}$ The attendant fear is that general elections are undermined if a newly elected government cannot change the law $^{3}$ because of international obligations entered into by the old government. ${ }^{4}$

Mega-regionals are transcontinental trade and investment agreements that account for a substantial share of world trade: the Transatlantic Trade and Investment Partnership (TTIP) and CETA connect North America with Europe; the TPP connects Pacific Rim countries; and

\footnotetext{
* This article draws on C. Riffel, 'Mega-Regionals' in R. Wolfrum and F. Lachenmann (eds), Max Planck Encyclopedia of Public International Law Thematic Series vol.1 International Economic Law (OUP 2016).

1 'Wallonia is Adamantly Blocking the EU's Trade Deal with Canada' (22 October 2016) The Economist.

2 S. Lester, 'Rethinking the International Investment Law System' (2015) 49 Journal of World Trade 211, 216.

3 Without the consent of the other contracting parties.

4 J. Stiglitz, Beware of TPP's Investor - State Dispute Settlement Provision (Roosevelt Forward 28 March 2016), available at http://rooseveltforward.org/ (accessed 27 March 2017).
} 
the Regional Comprehensive Economic Partnership (RCEP) connects Asia with Australia and New Zealand. The parallel negotiation of these mega-regionals made international economic law one of the most dynamic areas of international law in recent years. The North American Free Trade Agreement (NAFTA) ${ }^{5}$ served as a model for the TPP; and CETA is widely seen as a stepping stone for TTIP.

The Waitangi Tribunal held in 2016 that the TPP is not at variance with the principles of the Treaty of Waitangi in New Zealand. ${ }^{6}$ In Germany, a case was brought against CETA before the Federal Constitutional Court on sovereignty grounds; applications for a preliminary injunction seeking to enjoin Germany from signing CETA did not succeed. ${ }^{7}$ A similar complaint is pending in Canada. ${ }^{8}$ Creeping loss of sovereignty, actual and alleged, was one of the reasons that lead to Brexit. Yet, this is not a new phenomenon. For the same reason, the US Congress rejected the Havana Charter in 1950, which would have created the International Trade Organization, the precursor to the World Trade Organization (WTO). ${ }^{9}$

\section{Interplay between Sovereignty, Regulatory Autonomy, and Democracy}

One can see the building of the world economic order as the struggle to strike a balance between the regulatory autonomy of States, on the one hand, and the prerequisites for a functioning system, on the other hand. ${ }^{10}$ The more is regulated internationally, the less autonomy is left to national lawmakers. When building a bridge from two sides, both parties need to agree on the height, width and position of the bridge to be built. To that extent the parties have to constrain themselves for the two ends to fit.

National sovereignty is acknowledged in Art. 2 (7) Charter of the United Nations (UN Charter). ${ }^{11}$ Making international commitments, in a sense, is an expression of sovereignty. ${ }^{12}$ When a pollutant is carcinogenic and States therefore agree for public health reasons to ban that pollutant within their respective territories, they thereby restrict their sovereignty. If the party to a treaty is a democracy, the consequent loss of sovereignty is generally accompanied by a loss of democracy, as the international regime is not committed to democratic

5 North American Free Trade Agreement (adopted 17 December 1992, entered into force 1 January 1994) (1993) 32 ILM 289.

6 Report on the Trans-Pacific Partnership Agreement (Waitangi Tribunal 2016) 52.

7 German Federal Constitutional Court, 'Applications for a Preliminary Injunction in the "CETA" Proceedings Unsuccessful' (Press Release 71/2016, 13 October 2016), available at www.bundesverfassungsgericht.de/EN/Homepage/home_node.html (accessed 27 March 2017).

8 S. Lester, Canadian Constitutional Challenge to CETA (IELP Blog, 1 November 2016), available at http://worldtradelaw.typepad.com (accessed 27 March 2017).

9 M. Trebilcock, R. Howse and A. Eliason, The Regulation of International Trade (Routledge 2013) 24.

10 For the WTO Agreement on Technical Barriers to Trade (TBT Agreement), see WTO United States Measures Affecting the Production and Sale of Clove Cigarettes - Report of the Appellate Body (24 April 2012) WT/DS406/AB/R, 174: 'the object and purpose [...] is to strike a balance between, on the one hand, the objective of trade liberalization and, on the other hand, Members' right to regulate.' See also M. Wagner, 'Regulatory Space in International Trade Law and International Investment Law’ (2014) 36 University of Pennsylvania Journal of International Law 1, 15.

11 Charter of the United Nations (adopted 26 June 1945, entered into force 24 October 1945) 1 UNTS 16.

12 WTO China - Measures Related to the Exportation of Various Raw Materials - Reports of the Panel (22 February 2012) WT/DS394/R, WT/DS395/R, WT/DS398/R and Corr.1, 7.382. See also N. Tsagourias, 'The Legal Status of Cyberspace' in N. Tsagourias and R. Buchan (eds), Research Handbook on International Law and Cyberspace (Edward Elgar 2015) 28. 
representation. ${ }^{13}$ The more integrative the regime, the more pressing the issue of democratic feedback. The European Union sought to address this problem through the creation of the European Parliament and extending its competences over time. ${ }^{14}$ However, an even greater diminution of powers of national parliaments tends to ensue from the realization of more democracy at the international level, because competences are taken away from national legislative bodies and allocated to the international institution. This reveals a potential conflict between regulatory autonomy, i.e. State sovereignty, and the principle of democracy.

Why are mega-regionals special? Mega-regionals increase the level of trade liberalization among constituent members beyond the most-favoured-nation (MFN) level of the Agreement Establishing the World Trade Organization (WTO Agreement). ${ }^{15}$ However, mega-regionals are not only directed at trade liberalization. ${ }^{16}$ Their main thrust appears to be standard- and rulesetting. ${ }^{17}$ Consequently, their regulatory scope exceeds that of the WTO. They contain, for instance, chapters on 'trade and' topics such as labour. ${ }^{18}$ Moreover, the TPP is the first agreement to proactively tackle currency manipulation. ${ }^{19}$ As a corollary, the WTO Agreement merely sets the framework within which mega-regionals will operate, linked to the WTO by virtue of Art. XXIV General Agreement on Tariffs and Trade (GATT) ${ }^{20}$ and Art. V General Agreement on Trade in Services (GATS). ${ }^{21}$ Wherever a mega-regional provides special rules for the relationship between members, those rules will prevail in lieu of WTO rules.

\section{Loss of Sovereignty Resulting from Mega-Regionals}

In the past, the discussion on free trade agreements (FTAs) focussed on the interaction between these agreements and the WTO and the question of whether the former are conducive to the latter or a threat to it. ${ }^{22}$ In the context of mega-regionals, the focus is on the implications which mega-regionals have for the domestic legal order. The secrecy surrounding their negotiation and high-profile cases like the Plain Packaging ${ }^{23}$ cases only reinforced the above-mentioned

13 For the WTO, see M. Krajewski, 'Democratic Legitimacy and Constitutional Perspectives of WTO Law' (2001) 35 Journal of World Trade 167, $175 \mathrm{ff}$.

14 See, e.g., the Provisions on Democratic Principles in Title II of the Treaty on European Union (signed 7 February 1992, entered into force 1 November 1993) [1992] OJ C191/1.

15 Marrakesh Agreement establishing the World Trade Organization (adopted 15 April 1994, entered into force 1 January 1995) 1867 UNTS 154.

16 Cf. the Preambles to the TPP and CETA.

17 M. Herdegen, Principles of International Economic Law (OUP 2016) 341; Mega-Regional Trade Agreements: Game-Changers or Costly Distractions for the World Trading System? (World Economic Forum 2014) 20-21, 37.

18 Ch. 19 TPP, ch. 23 CETA.

19 Joint Declaration of the Macroeconomic Policy Authorities of Trans-Pacific Partnership Countries.

20 General Agreement on Tariffs and Trade 1994 (adopted 15 April 1994, entered into force 1 January 1995) 1867 UNTS 187.

21 General Agreement on Trade in Services (adopted 15 April 1994, entered into force 1 January 1995) 1869 UNTS 183. See Art. 1.1 TPP, Art. 1.4 CETA.

22 See, e.g., R. Baldwin, 'Preferential Trading Arrangements' in A. Narlikar, M. Daunton and R.M. Stern (eds), The Oxford Handbook on The World Trade Organization (OUP 2012) 632ff.

23 See, e.g., Philip Morris Asia Limited v Australia (Award on Jurisdiction and Admissibility) Permanent Court of Arbitration, Case No 2012-12 (17 December 2015). 
misgivings. ${ }^{24}$ When the TPP was negotiated, the participants agreed to a confidentiality agreement. ${ }^{25}$ Only after considerable public pressure and a Decision of the European Ombudsman to that effect ${ }^{26}$ has the European Commission released its TTIP negotiating documents. To hold negotiations of mega-regionals in a transparent way that involves all relevant stakeholders (e.g., by including representatives of the legislative branch in the negotiation teams) is not only important to ensure ratification down the road, but also because these mega-regionals have a systemic bearing on participating economies, more so than other FTAs. They will determine the parameters of how to do business. With good reason, Petersmann calls them 'international treaties with legislative functions. ${ }^{27}$

The quandary of mega-regionals lies in the fact that, by nature, the regulation of trade and foreign investment is internationalized, whereas adjacent policy fields such as consumer safety are left to national legislatures (which are or are not democratically legitimized). From an international perspective, there are regulatory gaps. From a national perspective, the crux is whether sufficient policy space is left to protect public welfare objectives. The underlying issue is with how much of their sovereignty countries are willing to dispense for the sake of global governance.

The danger from a national vantage point is that the international regime develops a life of its own. If the national legislature is a democratically elected body, the concern is that competences are shifted to regulatory bodies, established under mega-regionals, through builtin further integration clauses, for example, under the heading of regulatory cooperation. ${ }^{28}$ It is feared that those clauses enable governments to approximate national laws without parliamentary approval. Under the TPP and CETA, the representatives on the respective regulatory cooperation bodies ${ }^{29}$ will be government officials only, not parliamentarians. ${ }^{30}$ Panels, by contrast, are pre-empted from adding to or diminishing the rights and obligations of the parties under those agreements. ${ }^{31}$

The legal means employed to keep the intrusion into the national legal order in check, that is, to preserve regulatory autonomy, is the topic of the present paper. It ventures to outline in part II the different approaches taken by negotiators to safeguard domestic policy space. These safeguards can be of a procedural or substantive nature. Part III concludes and makes policy recommendations, particularly for TTIP and RCEP, the negotiations of which are still ongoing.

24 E. Petersmann, 'Transformative Transatlantic Free Trade Agreements without Rights and Remedies of Citizens?' (2015) 18 Journal of International Economic Law 579, 594.

25 Available at www.mfat.govt.nz/assets/_securedfiles/Trans-Pacific-Partnership/TPP-letter.pdf (accessed 27 March 2017).

26 European Ombudsman 'Decision of the European Ombudsman Closing Her Own-Initiative Inquiry OI/10/2014/RA concerning the European Commission' (6 January 2015).

27 Petersmann, 'Transformative Transatlantic Free Trade Agreements without Rights and Remedies of Citizens?' $596,603$.

28 Ch. 25 TPP, ch. 21 CETA.

29 Committee on Regulatory Coherence in the TPP; Regulatory Cooperation Forum in CETA; Regulatory Cooperation Body in TTIP, as proposed by the European Union.

30 Art. 25.6.1 TPP, Art. 21.6.3 CETA.

31 Art. 28.12.3, third sentence TPP; Art. 29.18 CETA. 


\section{Safeguards against Sovereignty Loss}

The trend towards mega-regionals is fuelled by the failure of the Doha Round, where it has proved increasingly difficult to reach agreement among the membership of currently 164 countries. ${ }^{32}$ As a preliminary point, it should be noted that mega-regionals are not concerned with the economic rights of nationals. New Zealand, for instance, cannot violate the TPP visà-vis New Zealanders, as a transaction between two New Zealanders taking place in New Zealand would not be governed by the TPP. The supply of goods and services from the South Island to the North Island would be governed by New Zealand law, as would the acquisition of a company in Christchurch by a New Zealander. That said, intellectual property (IP) holders are going to benefit from generally higher levels of protection resultant from the TPP in their own countries. Unlike the Agreement on Trade-Related Aspects of Intellectual Property Rights (TRIPS Agreement), ${ }^{33}$ which obligates the WTO Members to 'accord the treatment provided for in this Agreement to the nationals of other Members, ${ }^{34}$ ch. 18 (Intellectual Property) of the TPP does not contain a similar limitation to nationals of other TPP Members. ${ }^{35}$ Ergo, one IP standard is to be applied across the board. This TRIPS-plus standard will have to be multilateralized, because, unlike GATT and GATS, the TRIPS Agreement does not have an economic integration exception clause. ${ }^{36}$

\section{No Direct Effect}

Mega-regionals do not pursue the goal of political integration. The lack of a secretariat in the TPP and CETA speaks volumes in that regard. In line with this, mega-regionals have no direct effect in the legal order of the members; monist members that is, as direct effect is inconceivable in dualist countries. ${ }^{37}$ Not only do mega-regionals not prescribe direct effect, they even go one step further and explicitly proscribe a right of action against another member under domestic law. ${ }^{38}$ Even if a monist system did not negate direct effect, this does not say anything about the status international rules have in the internal hierarchy of norms. Should they be at the same level as statutes, as is the case more often than not, they would not take precedence over an act of parliament that is at odds with international law.

From the denial of direct effect, the following follows: Firstly, mega-regionals have to be implemented into national law and only the act of implementation creates legal effects in the national legal order. Secondly, the denial gives States the leeway to break their international obligations, at least from a national law perspective. Failing that, that is, if direct effect was a

32 B. Hoekman, 'Sustaining Multilateral Trade Cooperation in a Multipolar World Economy' (2014) 9 The Review of International Organizations 241, 243, 249; D.A. Gantz, Liberalizing International Trade after Doha: Multilateral, Plurilateral, Regional, and Unilateral Initiatives (CUP 2013) 46ff.

33 WTO Agreement on Trade-Related Aspects of Intellectual Property Rights, Including Trade in Counterfeit Goods (signed 15 April 1994, entered into force 1 January 1995) 1869 UNTS 299.

34 Art. 1.3, first sentence TRIPS Agreement.

35 Leaving the national treatment obligation aside, the only reference to 'nationals of another Party' is to be found in Art. 18.62.1 TPP with respect to related rights.

36 S. Bernstein and E. Hannah, 'The WTO and Institutional (In)Coherence in Global Economic Governance' in A. Narlikar, M. Daunton and R.M. Stern (eds), The Oxford Handbook on the World Trade Organization (OUP 2012) 792.

37 J.H. Jackson, 'Status of Treaties in Domestic Legal Systems: A Policy Analysis' (1992) 86 American Journal of International Law 310, 338.

38 Art. 28.22 TPP, Art. 30.6.2 CETA. 
reality, States would be deprived of this option of 'efficient breach. ${ }^{39}$ In that sense, the national legal system is shielded from international law. At the same time, this puts a stop to the development that the EU Treaties took, viz. into 'a new legal order of international law. ${ }^{40}$ In the final analysis, policy space is gained by less strict compliance with international law.

\section{a. No Redress under Domestic Law}

The other side of the coin is that, absent direct effect, domestic courts could not remedy a violation of mega-regionals because national rules are not measured against international law. Given that domestic courts are bound by domestic law, they can only provide redress as long as domestic law is in conformity with mega-regionals. Still, they would need to flesh out the interpretive scope that domestic law provides consistently with international law (doctrine of consistent interpretation). ${ }^{41}$ This emanates from the obligation in Art. 26 Vienna Convention on the Law of Treaties (Vienna Convention) ${ }^{42}$ to perform a treaty 'in good faith., 43

\section{i. Discrimination of Foreign Investors under Domestic Law}

So the question is whether national law affords the same guarantees as international law. ${ }^{44}$ In the context of the TTIP negotiations, the argument was put forward that both contracting parties, the United States and the European Union, have an independent court system, well capable of dispensing justice to investors from the other party. ${ }^{45}$ Interestingly, the suspended Canada-US FTA did not contain an ISDS clause; nor does the Australia-New Zealand Investment Protocol on account of 'the high level of mutual recognition of each other's well established judicial systems. ${ }^{46}$ The TPP will not alter that. ${ }^{47}$

With respect to some rights and obligations, US and EU law afford an equivalent level of protection. For instance, both parties recognize a right to property, which encompasses the

39 For a critical discussion of the theory of efficient breach, see P. Eeckhout, 'Remedies and Compliance' in Daniel Bethlehem et al. (eds), The Oxford Handbook of International Trade Law (OUP 2009) 446ff.

40 Case 26/62 NV Algemene Transport - en Expeditie Onderneming van Gend \& Loos v Netherlands Inland Revenue Administration [1963] ECR 1.

41 K. Kaiser, 'Treaties, Direct Applicability' in R. Wolfrum and F. Lachenmann (eds), Max Planck Encyclopedia of Public International Law (OUP 2013) 27.

42 Vienna Convention on the Law of Treaties (concluded 23 May 1969, entered into force 27 January 1980) 1155 UNTS 331.

43 Cf. WTO United States - Continued Dumping and Subsidy Offset Act of 2000 - Report of the Appellate Body (27 January 2003) WT/DS217/AB/R, WT/DS234/AB/R, 296.

44 For an assessment of the situation in Canada, see A. de Mestral and R. Morgan, 'Does Canadian Law Provide Remedies Equivalent to NAFTA Chapter 11 Arbitration?' (May 2016) Investor-State Arbitration Series Paper No. 4, available at www.cigionline.org/ (accessed 27 March 2017).

45 Petersmann, 'Transformative Transatlantic Free Trade Agreements without Rights and Remedies of Citizens?' 599-600. See also Rule of Law Index (World Justice Project 2015), available at http://data.worldjusticeproject.org/ (accessed 27 March 2017).

46 New Zealand Ministry of Foreign Affairs and Trade, Protocol on Investment to the New Zealand-Australia Closer Economic Relations Trade Agreement: National Interest Analysis 25, available at www.mfat.govt.nz/assets/_securedfiles/FTAs-agreements-in-force/Australia/Australia-NZ-CER-NIA.pdf (accessed 27 March 2017).

47 Para. 4 New Zealand-Australia Side Letter on the Relationship between TPP and Other Agreements, available at www.tpp.mfat.govt.nz/text (accessed 27 March 2017). 
property of foreigners. Both legal systems acknowledge an obligation of the State to compensate when the State dispossesses someone of its property. ${ }^{48}$ Both guarantee a right to be heard in their domestic laws. ${ }^{49}$ Importantly, both orders acknowledge that those rights also apply to non-citizens; the respective legal texts speak of 'person' or 'everyone. ${ }^{50}$ In the case of the United States and the European Union, the aforementioned rights have constitutional status. But there are other rights that are not equally reflected in the national legal orders, for example, fair and equitable treatment (FET). Those investors' rights would lack a remedy without ISDS and require the involvement of the investor's State of nationality.

\section{ii. Discrimination of Nationals as a Result of ISDS ${ }^{51}$}

The opposite question, namely discrimination of nationals as a result of ISDS, is pending before the German constitutional court, the Federal Constitutional Court. The applicants challenge the fact that, as compared to nationals, foreign investors have an additional avenue to pursue their interests. ${ }^{52}$ It is contested whether the envisaged establishment of the CETA Tribunal $^{53}$ is at variance with the German constitution, notably Art. 3 (1) Basic Law, because legal standing is conferred on foreign investors, but not on nationals. ${ }^{54}$

Art. 3 (1) Basic Law establishes the principle of equality before the law for the German legal order. It reads as follows: 'All persons shall be equal before the law. ${ }^{55}$ This precept binds all branches of German government, including the legislature. ${ }^{56}$ It obligates the German legislature to treat as equal what is basically equal and as different what is basically different. ${ }^{57}$ Thus, the German legislature must ensure equality before German law, i.e., the law the legislature is responsible for. What about equality before international law? The issue in the present case is whether the principle of equality precludes Germany from acceding to an international regime that grants foreigner investors procedural rights that are not available to national investors.

At this juncture, it bears recalling that international law is not concerned with the discrimination of nationals. Investment law sets an international minimum standard whose purpose it is to protect foreigners, not nationals. In short, CETA does not guarantee German

48 For the European Union, see Art. 17 (1) Charter of Fundamental Rights of the European Union (done 7 December 2000, entered into force 1 December 2009) (2001) 40 ILM 266; for EU Member States, see Art. 1 (1) Protocol 1 to the European Convention for the Protection of Human Rights and Fundamental Freedoms (signed 4 November 1950, entered into force 3 September 1953) 213 UNTS 221 (ECHR). For the United States, see the $5^{\text {th }}$ Amendment to the US Constitution.

49 For the European Union/Member States, see Art. 41 (2) (a) Charter of Fundamental Rights and Art. 6 (1) ECHR. For the United States, see the $5^{\text {th }}$ Amendment and $14^{\text {th }}$ Amendment, Sec. 1.

50 See also Art. 1 ECHR.

51 An earlier version of this section was pre-published on the IELP Blog (9 October 2016), available at http://worldtradelaw.typepad.com (accessed 27 March 2017).

52 S. Lester, The German Constitutional Complaint on CETA (IELP Blog 27 September 2016), available at http://worldtradelaw.typepad.com (accessed 27 March 2017).

53 Art. 8.27 CETA.

54 Arts. 8.18, 8.23.1 CETA.

55 German lexts available in tenglish at www.bundesverfassungsgericht.de/EN/Verfahren/Rechtsquellen/rechtsquellen_node.html (accessed 27 March 2017).

56 Art. 1 (3) Basic Law.

57 See, e.g., BVerfGE, Judgment of the First Senate of 30 July 2008, 1 BvR 3262/07, 150. 
investors any rights in Germany. Still, both German and Canadian investors in Germany have an international avenue at their disposal where they can pursue their proprietary interests: Foreign investors will be able to rely on CETA. The 'possessions' held by Germans in Germany are protected internationally by virtue of Art. 1 Protocol to the European Convention on Human Rights (ECHR). That is, the designated forum before which Germans can assert their proprietary interests against the German government, after having exhausted all domestic remedies, ${ }^{58}$ is the European Court of Human Rights. Unlike the German constitutional court, which can void a law that violates the German constitution, the European Court of Human Rights does not have the authority to void national law that is inconsistent with the ECHR. Instead, the Court can find a violation of the Convention and grant 'just satisfaction' within the meaning of Art. 41 ECHR, which encompasses pecuniary damages. ${ }^{59}$

On a related note, Canadians within the jurisdiction of Germany enjoy the rights and freedoms of the ECHR. ${ }^{60}$ Contrariwise, the basic rights of the German constitution, such as the protection of property in Art. 14 Basic Law, do not apply to Canadian juridical persons. ${ }^{61}$ Hence, Canadian companies may have standing before the European Court on Human Rights, but cannot challenge German law before the Federal Constitutional Court. Commensurate with German law, the seat of a juridical person determines whether it is treated as 'domestic' within the meaning of Art. 19 (3) Basic Law. ${ }^{62}$ If a foreign company operates through a subsidiary established in Germany, the subsidiary is deemed to be domestic from the point of view of German law. ${ }^{63}$ That is to say, the subsidiary could invoke Art. 14 Basic Law in a constitutional complaint. ${ }^{64}$

Any claim of inequality presupposes comparability. The comparators at issue are national investors as governed by German law, on the one hand, and foreign investors as protected under CETA, on the other hand. Art. 3 (1) Basic Law would not apply if the unequal treatment could be ascribed to different legislatures. ${ }^{65}$ Thus, the Federal Constitutional Court did not find a violation of Art. 3 (1) Basic Law when Germans residing in one federal State had special privileges on the basis of a State law that deviated from the federal law or the law of other States, privileges which were not obtainable to Germans residing somewhere else in the Federal Republic. ${ }^{66}$ Nonetheless, the prevailing view regards Art. 3 (1) Basic Law as applicable to situations where the discrimination of nationals results from European Union law. ${ }^{67}$ Following this, Art. 3 (1) Basic Law can remedy the discrimination of nationals by forcing the German government to treat Germans like EU citizens.

\footnotetext{
58 Art. 35 (1) ECHR.

59 See European Court of Human Rights, 'Practice Direction - Just satisfaction claims' (1 January 2016), available at www.echr.coe.int/Documents/PD_satisfaction_claims_ENG.pdf (accessed 27 March 2017) 10-12.

60 Art. 1 ECHR.

61 Art. 19 (3) Basic Law.

62 BVerfGE, Order of the First Senate of 19 July 2011, 1 BvR 1916/09, 71, 79; BVerfGE, Order of the Second Chamber of the First Senate of 18 January 2002, 1 BvR 2284/95, 14; H.D. Jarass and B. Pieroth, Grundgesetz für die Bundesrepublik Deutschland (C.H. Beck 2016) 22 (Art. 19); D. Schroeder, Grundrechte (C.F. Müller 2016) 27.

63 M. Sachs, Grundgesetz (C.H. Beck 2014) 54 (Art. 19).

64 BVerfGE, Order of the First Senate of 19 July 2011, 1 BvR 1916/09, 69.

65 H.-J. Papier and C. Krönke, Grundkurs Öffentliches Recht 2: Grundrechte (C.F. Müller 2015) 103; T. Kingreen and R. Poscher, Grundrechte: Staatsrecht II (C.F. Müller 2016) 485.

66 BVerfGE, Order of the Second Senate of 30 May 1972, 2 BvL 41/71, 35.

67 Jarass and Pieroth, Grundgesetz für die Bundesrepublik Deutschland 75a (Art. 3).
} 
It is true that the German legislature is involved in the making of international law when, for example, ratifying a treaty in accordance with Art. 14 Vienna Convention. However, CETA is a mixed agreement, undergoing ratification at both EU and Member State level. ${ }^{68}$ As to 'foreign direct investment,' the European Union has the exclusive competence pursuant to Art. 3 (1) (e) in conjunction with Art. 207 (1) Treaty on the Functioning of the European Union (TFEU). ${ }^{69}$ This includes the resolution of investment disputes. ${ }^{70}$ As it falls within the purview of the European legislature, the German ratification act to CETA would not concern the investment chapter thereof.

All things considered, we can conclude that different legislatures are responsible for the treatment of foreign investors, on the one hand, and national investors, on the other hand. Consequently, the precondition for an application of Art. 3 (1) Basic Law is not given, namely comparability. The German legislature could not accord to nationals the same treatment as to foreign investors and, without the consent of Canada and the European Union, grant nationals legal standing before the CETA Tribunal. It would lack the competence to do so. In the final analysis, Art. 3 (1) Basic Law does not guarantee equal access of nationals to international tribunals, only to courts within the jurisdiction of the Federal Republic. Things are less straightforward for Germany's bilateral investment treaties (BITs) with an ISDS clause, as in these cases Art. 3 (1) Basic Law would not be ruled out a priori. Those BITs shall be replaced step by step by EU treaties. ${ }^{71}$

\section{b. Resolution of Investment Disputes}

Some countries, e.g. Australia and India, are contemplating scrapping ISDS altogether. ${ }^{72}$ Others have withdrawn from the International Centre for Settlement of Investment Disputes. ${ }^{73}$ However, to be effective, rules need to be enforceable. This is true of rules of national as well as international law. ${ }^{74}$ The aforementioned enforcement deficit caused by the lack of direct effect is exactly the gap that ISDS seeks to fill. Besides, in some cases, the rights of non-citizens may not be easily discernible. The national law definition of what constitutes 'property' is not necessarily congruent with the international understanding of 'investment.' ISDS thus reduces the legal risk for investors going into a foreign jurisdiction, which is one factor in their overall risk assessment.

68 For the European Union, see Arts. 207, 216 TFEU. For Germany, see Art. 59 (2) Basic Law.

69 Treaty on the Functioning of the European Union (signed 13 December 2007, entered into force 1 December 2009) [2008] OJ C115/47.

70 M. Hahn, 'Art. 207' in C. Calliess and M. Ruffert (eds), EUV/AEUV (C.H. Beck 2016) 30. See Recitals 1 and 2 of Regulation (EU) No. 912/2014 of the European Parliament and of the Council of 23 July 2014 establishing a framework for managing financial responsibility linked to investor-to-State dispute settlement tribunals established by international agreements to which the European Union is party.

71 European Commission, Investment (Directorate-General for Trade 9 October 2015), available at http://ec.europa.eu/trade/ (accessed 27 March 2017).

72 L. Trakman, 'Australia's Rejection of Investor-State Arbitration: a Sign of Global Change' in L. Trakman and N. Ranieri (eds), Regionalism in International Investment Law (OUP 2013) 344ff. See, e.g., Art. 11.16 AustraliaUnited States FTA, available at https://ustr.gov (accessed 27 March 2017).

73 Venezuela, Ecuador, Bolivia. See ISCID 'List of Contracting States' (2016), available at https://icsid.worldbank.org/apps/ICSIDWEB/Pages/default.aspx (accessed 27 March 2017).

74 For WTO rules, see W. Davey, 'The WTO Dispute Settlement Mechanism' in J.H.B. Pauwelyn, A.T. Guzman and J.A. Hillman, International Trade Law (Aspen 2016) 128, 130. 
Moreover, a report of the World Economic Forum shows that the court systems of some countries are notoriously biased towards the national government. ${ }^{75}$ Some of them are designated members of mega-regionals. So it would be hard, particularly for a foreigner, to take the State to court (and get a just ruling) in countries where the courts basically function as an extended arm of the government. It is worth calling to mind that Art. 26 Convention on the Settlement of Investment Disputes between States and Nationals of Other States (ICSID Convention $)^{76}$ provides that, as a rule, consent to ISDS excludes local remedies.

One of the criticisms levelled at ISDS is that it mainly serves the interests of multinational corporations, i.e. particular entities. ${ }^{77}$ By their very nature, it is difficult to think of them in terms of national/foreign, one of the premises of investment law. ${ }^{78}$ Private entities take legal action against governments in administrative proceedings all the time. That they can do so is considered a hallmark of the rule of law. It is evident, however, that resources are necessary (e.g. for legal expenses) to take full advantage of ISDS. No difference is made depending on the legal nature of the private entity, be it a natural or juridical person. Juridical persons are used by natural persons, for instance, to limit their personal liability.

The ultimate objective of investment protection is to rein in arbitrary law-making of the host State. It is sometimes criticized that international investment law guarantees foreign investors rights without concurrently imposing obligations on them, for example, with respect to human rights or environmental protection. It seems axiomatic that property entails social responsibility. ${ }^{79}$ With that in mind, Lester laments a 'structural bias,' which stems from the fact that, while investors can take legal action against States, States cannot sue investors. ${ }^{80}$ In truth, States do not need to. They have the monopoly on use of force in their territory and can regulate the behaviour of foreign investors within their jurisdiction through legislative and administrative acts, which may be subject to scrutiny. Again, this is evocative of the similarity between investment and administrative law: an authority does not sue citizens in order to prompt a particular behaviour (e.g. the payment of a fee, the removal of a road obstacle, etc.), it issues an administrative act, the legality of which can then be challenged before the courts if citizens feel that their rights, e.g. constitutional guarantees, have been violated by that act. If a host State wants to force foreign investors to comply with, let us say, core labour standards, it can simply implement those into national law, thus making them mandatory for both foreign and national investors. In such a constellation, a foreign investor would be unable to invoke the concept of FET should it seek to evade core labour standards, as its expectations are to be based on the law, including the international law, as it stood when the investment was made. ${ }^{81}$

75 World Economic Forum, 'Competitiveness Rankings' (2015-2016) Judicial independence, available at http://reports.weforum.org/global-competitiveness-report-2015-2016/competitiveness-rankings/ (accessed 27 March 2017).

76 Convention on the Settlement of Investment Disputes between States and Nationals of Other States (opened for signature 18 March 1965, entered into force 14 October 1966) 575 UNTS 159.

77 See, e.g., 'Belgium Walloons Block Key EU Ceta Trade Deal with Canada' (24 October 2016) BBC. See also L. Cocq-Rasmussen, 'An Analysis of Geopolitical Considerations of Investor State Dispute Settlement and the Pursuit of Impartial Justice’ (2015) 7 Amsterdam Law Forum 36, 54.

78 Lester, 'Rethinking the International Investment Law System' $214 \mathrm{ff}$.

79 See, e.g., Art. 14 (2) German Basic Law ('Property entails obligations. Its use shall also serve the public good.'); Art. 1 (2) Protocol to the ECHR ('the right of a State to enforce such laws as it deems necessary to control the use of property in accordance with the general interest').

80 S. Lester, Gary Born Defending Investment Arbitration (IELP Blog 8 August 2016), available at http://worldtradelaw.typepad.com (accessed 27 March 2017).

81 See, e.g., Frontier Petroleum Services v The Czech Republic (Final Award) (12 November 2010) 287. 
Expectations of a foreign investor to the contrary would not be considered as legitimate. ${ }^{82}$ So a host State would be free to obligate a foreign investor to observe core labour standards as long as it did not discriminate. This would not be the case if a general law of the host State applied to foreign as well as national investors alike. According to the prevailing view, international human rights obligations are State obligations. ${ }^{83}$ That is, private entities, such as foreign investors, are not obliged to protect human rights, States are. ${ }^{84}$ Hence, States have to put in place mechanisms to that effect, which then apply to foreign investors as well.

Actually, it is not so much the provision of ISDS that divest States of their regulatory freedom, but the substantive rights, which suggests that negotiators should focus on them. ${ }^{85}$ Justiciability ensures compliance but does not add to the obligations States have under an agreement. Legal standing does not expand investors' rights ipso facto. It sets the stakes for non-compliance higher. The fact is bemoaned that investors' rights, i.e. proprietary and monetary interests, are better protected internationally than human rights. In truth, it is regularly national governments that perpetrate human rights violations against people within their jurisdiction. Investment law harks back to the law of aliens, which, in turn, is based on the fact that foreigners have no say in national policy-making as a matter of principle. ${ }^{86}$ As a rule, they are excluded from participating in general elections. Their home State cannot protect them in the territory of the host State by reason of national sovereignty. International investment law plugs that gap. The question is simple: would people invest hundreds of millions of dollars in a politically unstable country without international guarantees? Therefore, a State that is contemplating an international investment agreement without ISDS has to assess two things: firstly, whether the legal order of the other contracting parties provides adequate protection for investments of its own nationals, and secondly, whether inter-State adjudication will be sufficient to attract foreign direct investment. For the alternative to ISDIS is inter-State adjudication. If an ISDS clause exists, it will take precedence according to Art. 27 (1) ICSID Convention.

Trade disputes are resolved through inter-State adjudication, as traders have no legal standing. ${ }^{87}$ Their interests are represented by their home State. This poses the question of how the different treatment of traders and investors can be justified. In a nutshell, it is more at stake for investors because they cast in their lot with the host State. Whereas an exporter can sell elsewhere, an investor is stuck in the jurisdiction of the host State.

Should the negotiators have left the issue of dispute settlement unregulated, general international law would apply, i.e. the Articles on State Responsibility. ${ }^{88}$ A violation of investors' rights, e.g. an expropriation without compensation, could be answered by

82 For the relationship between the FET standard and the doctrine of legitimate expectations, see R. Dolzer and

C. Schreuer, Principles of International Investment Law (OUP 2012) 145ff. See also Art. 8.10.4 CETA.

83 H. Andersen, 'Protection of Non-Trade Values in WTO Appellate Body Jurisprudence: Exceptions, Economic Arguments, and Eluding Questions' (2015) 18 Journal of International Economic Law 383, 391.

84 O. De Schutter, International Human Rights Law: Cases, Materials, Commentary (CUP 2014) $427 \mathrm{ff}$.

85 See C. Henckels, 'Protecting Regulatory Autonomy through Greater Precision in Investment Treaties: The TPP, CETA, and TTIP' (2016) 19 Journal of International Economic Law 27.

86 S.P. Subedi, 'International Investment Law' in M.D. Evans (ed), International Law (OUP 2014) 729-730.

87 There is an exception in relation to antidumping and countervailing duty determinations, Art. 1904 NAFTA, Art. 3.2.3 CETA.

88 UNGA Res 56/83 'Responsibility of States for Internationally Wrongful Acts' (12 December 2001) GAOR 56th Session Supp 49 vol 1, 499. 
countermeasures by the home State. ${ }^{89}$ In concreto, this means the suspension of the rights of investors from the violating country. So for enforcement under general international law to be effective, nationals from both countries must have invested in the respective other country. Otherwise, the suspending country would have no leverage.

\section{c. Assessment}

The problem is rooted in the fact that tribunals deal with individual cases, while national legislatures are charged with weighing up competing societal interests in the abstract in light of scarcity of resources. Investment tribunals are criticized for not being democratically legitimized. When lamenting their lack of legitimacy, we also have to ask the question: legitimate in the eyes of whom - those whose case is adjudicated (foreign investors) or the general public?

In the context of adjudicatory bodies, legitimacy relates to the question of whether the power of such bodies is accepted by those subject to their authority. ${ }^{90}$ To ban popular vote from the courtroom is exactly the raison d'être of ISDS. The general public is represented by the government in international court proceedings. Tribunals are not democratically controlled but independent of popular influence for good - due process - reasons. Their function is to protect the individual against the tyranny of the majority.

This raises the question of standard of review. An international tribunal can either accept the legislative outcome as presented or substitute its own weighing-up for that of the legislature or scrutinize if the legislature acted arbitrarily (e.g., by not taking into account all relevant interests). If a tribunal simply accepted the legislative outcome, even if the result of a democratic process, the tribunal would not live up to its mandate. On the other hand, if the tribunal nolens volens replaced the legislative weighing-up with its own, it would not show any deference to the democratic decision. In the author's view, the solution is to be found in the proper calibration of the proportionality test. ${ }^{91}$

The European Union and Canada broke the mould with CETA and proposed a standing body with an appeal mechanism instead of ad hoc tribunals. Future developments have to be awaited.

\section{Jurisdictional Carve-outs}

\section{a. Carve-out in CETA}

Another way to strengthen regulatory autonomy is to curtail the jurisdiction of tribunals by excluding either particular provisions or even entire policy fields. Art. 8.18.1 lays out the scope of ISDS for the purposes of CETA. It does neither encompass Section B, the establishment of investments, nor the national treatment obligation in Section $\mathrm{C}^{92}$ with respect to the establishment and acquisition of investments. It follows from this that the pre-entry stage is not covered. Hence, foreign investors could not sue for market access under CETA.

89 Arts. 49ff Articles on State Responsibility.

90 Krajewski, 'Democratic Legitimacy and Constitutional Perspectives of WTO Law' 168-169.

91 See also C. Henckels, 'Indirect Expropriation and the Right to Regulate: Revisiting Proportionality Analysis and the Standard of Review in Investor-State Arbitration' (2012) 15 Journal of International Economic Law 223, 224ff; Trebilcock, Howse and Eliason, The Regulation of International Trade 497.

92 Art. 8.6 CETA. 
This is different for the TPP. The investment chapter therein is comprised of two sections: Section A contains investors' rights and Section B provides for ISDS. According to Art. 9.19.1 TPP, all substantive rights set forth in Section A are actionable, including the full national treatment obligation in Art. 9.4 TPP. This provision is modelled on Art. 1102 NAFTA. Both NAFTA and the TPP extend the national treatment obligation to the establishment and acquisition of investments. It is accepted that Art. 1102 NAFTA ensures market access. ${ }^{93}$ As far as the TPP is concerned, this result is borne out by the fact that, in Annex II, Members reserved the right to approve (and refuse) investments beyond a particular threshold, as spelled out in their respective foreign investment regimes. ${ }^{94}$ This shows, by implication, that market access is granted in principle. Otherwise, there would have been no need to include those reservations into the list of non-conforming measures.

\section{b. Carve-out in the TPP}

Instead of undercutting market access, the TPP gives the option to declare tobacco control measures non-actionable. ${ }^{95}$ It is questionable what the tobacco carve-out in Art. 29.5 TPP means for ISDS under NAFTA, given that all NAFTA States signed the TPP. Can tobacco companies resort to NAFTA tribunals with a view to circumventing the TPP carve-out? First of all, it should be noted that the carve-out could not be sidestepped by invoking the MFN obligation, as this obligation 'does not encompass international dispute resolution procedures or mechanisms. ${ }^{96}$ Pursuant to Art. 1.2.1 (b) TPP, the TPP is intended to coexist with NAFTA. Yet, each NAFTA Party merely 'affirms' its rights and obligations under NAFTA. Art. 1.2.1 (b) TPP does not specify that the TPP 'is not to be considered as incompatible with' NAFTA in terms of Art. 30 (2) Vienna Convention. Rather, the TPP has a specific conflict clause: should the TPP be incompatible with NAFTA, Art. 1.2.2 TPP provides a special consultation procedure, which is modelled on Art. 2 (3) (Chapter 18) ASEAN-Australia-New Zealand FTA. Footnote 1 to Art. 1.2.2 TPP states that

the fact that an agreement provides more favourable treatment of ... investments ... than that provided for under this Agreement does not mean that there is an inconsistency.

Accordingly, the more favourable treatment of tobacco investments in NAFTA does not amount to an inconsistency within the meaning of the TPP. NAFTA prevails wherever it provides more favourable investment protection. It follows that the TPP carve-out does not apply to NAFTA Parties.

It bears emphasizing that the tobacco carve-out is not mandatory. The TPP Parties 'may' opt out of ISDS with respect to tobacco control measures as defined in footnote 13 to Art. 29.5 TPP. That is, they have discretion. The exercise of this discretion is restricted for NAFTA Parties by virtue of the affirmation in Art. 1.2.1 (b) TPP. In summary, even with the TPP being in force, there can still be disputes relating to tobacco control measures between an investor from a NAFTA State and another NAFTA State, but not other TPP Members, provided they

93 I. Gómez-Palacio and P. Muchlinski, 'Admission of Investment and Right of Establishment' in P. Muchlinski,

F. Ortino and C. Schreuer (eds), The Oxford Handbook of International Investment Law (OUP 2008) 243.

94 Annex II New Zealand 7f; Annex II Australia 6.

95 Art. 29.5 TPP.

96 Art. 9.5.3 TPP. 
opted out, nor between an investor from a TPP Member that is not a NAFTA Party and a NAFTA Party.

On a related note, it is disputed whether the later introduction of a jurisdictional carve-out would violate an existing FET standard in a treaty. ${ }^{97}$ However, only domestic acts of the host State are measured against the international minimum standard. To review the further concretization of that standard (through treaty amendment) in light of the extant standard would give it an absolute status that it does not have, viz. that of a peremptory norm of international law. ${ }^{98}$ Consequently, a ratification act to amend a treaty cannot violate that treaty; it could only violate jus cogens.

\section{c. Assessment}

Neither CETA nor the TPP goes as far as the China-Australia FTA, which excludes ' $[\mathrm{m}]$ easures of a Party that are non-discriminatory and for the legitimate public welfare objectives of public health, safety, the environment, public morals or public order. ${ }^{, 99}$ Such measures are not subject to an ISDS claim. Instead, the matter goes to consultation with the State Parties. ${ }^{100}$

\section{Safeguards against Forum Shopping}

Not directly related to the issue of sovereignty loss, but still relevant because it increases the exposure to litigation, is the problem of forum shopping. There is a plethora of bilateral and plurilateral treaties between the parties to mega-regionals that will remain in force unless the parties agree otherwise. What complicates the matter is that some of these agreements are dovetailed with each other via their respective MFN clauses. Mega-regionals seek to cut through this spaghetti bowl of regulations in an attempt to lower transaction costs for businesses within the respective trade bloc. ${ }^{101}$ As far as investment law is concerned, they have the potential to consolidate the patchwork of bilateral investment treaties and to further legal certainty. ${ }^{102}$ Still, a problem for the future will be to harmonize the different sets of rules

97 S. Lester, Does a Tobacco Carveout FTA Amendment Violate International Investment Obligations? (IELP Blog 19 October 2016), available at http://worldtradelaw.typepad.com (accessed 27 March 2017).

98 Cf. N. Angelet, 'Fair and Equitable Treatment' in R. Wolfrum and F. Lachenmann (eds), Max Planck Encyclopedia of Public International Law (OUP 2011) 7.

99 Art. 9.11.4 China-Australia FTA (text available at http://dfat.gov.au/pages/default.aspx (accessed 27 March 2017)).

100 Art. 9.11.6 China-Australia FTA. For an overview, see A. Roberts and R. Braddock, 'Protecting Public Welfare Regulation Through Joint Treaty Party Control: A ChAFTA Innovation' (2016) Columbia FDI Perspectives, available at http://ccsi.columbia.edu/publications/columbia-fdi-perspectives/ (accessed 27 March 2017).

101 Tun-Jen Cheng and Wei-Chin Lee, 'Wrestling over the Trans-Pacific Partnership: US Strategic Interests, China's Responses, and Taiwan's Membership Options' in P.C.Y. Chow (ed), The Trans-Pacific Partnership and the Path to Free Trade in the Asia-Pacific (2016) 52; I. Barbee and S. Lester, 'The TPP and the Future of Trade Agreements' (2014) 2 Latin American Journal of International Trade Law 207, 213.

102 W. Alschner, 'Regionalism and Overlap in Investment Treaty Law: Towards Consolidation or Contradiction?' (2014) 17 Journal of International Economic Law 271, 273-274. 
stipulated in mega-regionals, e.g. different rules of origin, which distort trade and may amount to non-tariff barriers to trade. ${ }^{103}$

\section{a. Trade Disputes}

A clash of jurisdictions with the WTO dispute settlement mechanism is prevented by choiceof-forum and fork-in-the-road clauses. When the same case can be argued under both a megaregional and under the WTO Agreement, the complainant has a choice. ${ }^{104}$ Once dispute settlement proceedings are initiated under one of these agreements, that choice is final. ${ }^{105}$ Those clauses establish a pactum de non petendo between the disputing parties with respect to other forums not selected. The question is if Art. 30 (4) (a) Vienna Convention applies to the effect that the fork-in-the-road rule takes precedence over Art. 23 Dispute Settlement Understanding (DSU), ${ }^{106}$ which prescribes the exclusivity of the multilateral system. ${ }^{107}$

This issue was left open by the Appellate Body in Mexico - Taxes on Soft Drinks ${ }^{108}$ and only decided for the constellation where a fork-in-the-road clause was missing in the FTA. ${ }^{109}$ As long as the FTA is permitted by the WTO Agreement, ${ }^{110}$ the WTO adjudicatory bodies should show deference to the choice of forum made by the disputing parties. ${ }^{111}$ In Peru Agricultural Products, the Appellate Body accepted 'the relinquishment of the right to initiate WTO dispute settlement proceedings' in principle, ${ }^{112}$ but with the proviso that the relinquishment is confined to 'the settlement of specific disputes.' 113

\section{b. Investment Disputes}

If an investor is a multinational company, they can usually rely on more than one treaty, as exemplified in the $C M E /$ Lauder case (horizontal overlap). ${ }^{114}$ What if an investor has only one

103 J. Menon, 'From Spaghetti Bowl to Jigsaw Puzzle? Fixing the Mess in Regional and Global Trade' (2014) 1 Asia and the Pacific Policy Studies 470, 471ff; D.A. Gantz, 'Regional Trade Agreements' in D. Bethlehem et al. (eds), The Oxford Handbook of International Trade Law (OUP 2009) 237.

104 Art. 28.4.1 TPP, Art. 29.3.1 CETA.

105 Art. 28.4.2 TPP, Art. 29.3.2 CETA. See also Art. 2005.6 NAFTA.

106 WTO 'Understanding on Rules and Procedures governing the Settlement of Disputes' (adopted 15 April 1994 , entered into force 1 January 1995) 1869 UNTS 401.

107 WTO Canada-Continued Suspension of Obligations in the EC-Hormones Dispute - Report of the Appellate Body (14 November 2008) WT/DS321/AB/R, 371; WTO United States - Sections 301-310 of the Trade Act of 1974 - Report of the Panel (27 January 2000) WT/DS152/R, 7.43.

108 WTO Mexico - Tax Measures on Soft Drinks and Other Beverages - Report of the Appellate Body (24 March 2006) WT/DS308/AB/R, 54.

109 WTO Argentina - Definitive Anti-Dumping Duties on Poultry from Brazil - Report of the Panel (19 May 2003) WT/DS241/R, 7.38; Trebilcock, Howse and Eliason, The Regulation of International Trade 125, 128-129.

110 Art. XXIV GATT; Art. V GATS; GATT Decision on Differential and More Favourable Treatment: Reciprocity and Fuller Participation of Developing Countries (28 November 1979) GATT Doc L/4903 (Enabling Clause).

111 A.C. M. de Mestral, 'Dispute Settlement Under the WTO and RTAs: An Uneasy Relationship' (2013) Journal of International Economic Law 1, 42-43, 47-48.

112 WTO Peru - Additional Duty on Imports of Certain Agricultural Products - Report of the Appellate Body (31 July 2015) WT/DS457/AB/R, 5.25.

113 Ibid., footnote 106.

114 A. Reinisch, 'International Courts and Tribunals, Multiple Jurisdiction' in R. Wolfrum and F. Lachenmann (eds), Max Planck Encyclopedia of Public International Law (OUP 2011) 16-17. 
nationality? A Vietnamese investor in Malaysia, for instance, will be able to rely on the BIT between Malaysia and Vietnam, the ASEAN Comprehensive Investment Agreement (ACIA), and the TPP (vertical overlap). Both ACIA and TPP affirm existing rights and obligations. ${ }^{115}$ That is, the lex posterior rule as set out in Art. 30 (3) Vienna Convention does not apply. Should the final text of RCEP contain an investment chapter, there would be a fourth option. Not surprisingly, UNCTAD stated that:

With thousands of treaties, many ongoing negotiations and multiple dispute-settlement mechanisms, today's [international investment agreement] regime has come close to a point where it is too big and complex to handle for governments and investors alike. ${ }^{116}$

A vertical overlap is not conceivable in the context of Canada and the European Union. According to Art. 30.8.1, CETA replaces all BITs that EU Member States have with Canada. Art. 8.24 CETA regulates a possible horizontal overlap: the ISDS proceedings under CETA are to be stayed or have to take account of proceedings brought pursuant to another international agreement.

As far as the TPP is concerned, a provision along the lines of Art. 8.24 CETA is lacking and the fork-in-the-road clause in Art. 28.4.2 TPP does not cover ISDS disputes (only disputes between the Parties). Instead, the TPP avails itself of the principle of estoppel: Art. 9.21.2 (b) TPP requires a claimant to waive 'any right to initiate or continue before ... any other dispute settlement procedures, any proceeding with respect to any measure alleged to constitute a breach.' Another dispute settlement procedure in that sense would be, for example, a tribunal established under a BIT. The same regulatory technique is used in Art. 1121 (1) (b) NAFTA. ${ }^{117}$

\section{Other Procedural Safeguards}

\section{a. Safeguards against Frivolous Claims}

Frivolous claims are pre-empted. ${ }^{118}$ By quashing claims 'manifestly without legal merit' at an early stage, States save litigation costs, i.e. taxpayer's money.

\section{b. Adoption of Authoritative Interpretations}

A powerful tool to gain back control from the adjudicatory bodies is through the adoption of authoritative interpretations. These are binding upon tribunals. ${ }^{119}$ States can thereby interfere with ongoing disputes, thus readjusting the separation of powers between them and dispute settlement bodies. This shows that, when it comes to ISDS, the parties' right to regulate is given more weight than due process.

115 Art. 44 ACIA, Art. 1.2.1 (b) TPP.

116 UNCTAD, World Investment Report 2011: Non-Equity Modes of International Production and Development (2011) xvii.

117 Alschner, 'Regionalism and Overlap in Investment Treaty Law: Towards Consolidation or Contradiction?' 291.

118 Art. 9.23.4 TPP, Art. 8.32 CETA.

119 Art. 9.25.3 TPP, Art. 8.31.3 CETA. 
Like under NAFTA, ${ }^{120}$ the authority to issue interpretations under the TPP is limited to the investment chapter. As far as trade disputes are concerned, i.e. inter-State arbitration, TPP Members rely on the prohibition of an addition to or diminishment of rights and obligations, ${ }^{121}$ as known from Arts 3.2, third sentence, and 19.2 DSU. The purpose is to rein in a usurpation of competences by the back door. However, it is left to the adjudicatory bodies themselves to decide when this is the case.

In contrast, Art. IX:2 and 5 WTO Agreement additionally guarantees the WTO Members 'the exclusive authority to adopt interpretations,' and so does CETA. The Appellate Body observed in US-Clove Cigarettes that 'such interpretations are most akin to, but not exhaustive of, subsequent agreements on interpretation within the meaning of Art. 31 (3) (a) of the Vienna Convention.' ${ }^{122}$ According to Art. 26.1 .5 (e), the CETA Joint Committee may adopt interpretations that are binding on both investment and trade tribunals. ${ }^{123}$

Special rules exist for financial services and taxation measures. Committees comprising State representatives determine whether a prudential measure or a taxation measure is justified. ${ }^{124}$ Finally, Art. 9.26.2 TPP clarifies that it is the State Parties acting through the TPP Commission, not a tribunal, that delineate the scope of non-conforming measures.

\section{c. Selection of Arbitrators}

Moreover, States are capable of influencing tribunal procedures by appointing arbitrators to their liking. ${ }^{125}$ As the recent row over the reappointment of a member of the WTO Appellate Body illustrated, the same holds true for standing bodies. ${ }^{126}$ Whether taking influence in that way is conducive or detrimental to the legitimacy of the respective adjudicatory body is, of course, another question.

\section{d. Appeals Mechanism}

Finally, under CETA, the losing party to an investment dispute will be able to appeal to the Appellate Tribunal, established according to Art. 8.28. The TPP, by contrast, does not provide for an appellate review process.

\footnotetext{
120 Art. 1131 (2) NAFTA.

121 Art. 28.12.3 TPP, third sentence. For CETA, see Art. 29.18.

122 WTO United States - Measures Affecting the Production and Sale of Clove Cigarettes - Report of the Appellate Body 259 (emphasis in original).

123 Art. 26.1.5 (e) CETA.

${ }^{124}$ For prudential measures, see Art. 11.22.2 TPP, Art. 13.21.3 and 4 CETA. For taxation measures, see Art. 29.4.4 TPP, Art. 28.7.7 CETA.

125 Arts. 9.22, 28.9 TPP; Arts. 8.27-8.28, 29.7-29.8 CETA. See also A. von Bogdandy and I. Venzke, 'On the Democratic Legitimation of International Judicial Lawmaking' in A. von Bogdandy and I. Venzke (eds), International Judicial Lawmaking: On Public Authority and Democratic Legitimation in Global Governance (Springer 2012) 493ff.

126 G. Shaffer, The Appellate Body Reappointment Controversy (IELP Blog 23 May 2016), available at http://worldtradelaw.typepad.com (accessed 27 March 2017).
} 


\section{Non-Conforming Measures}

State Parties have the option to exclude entire government measures from the scope of a megaregional. This concerns existing measures as set out in Annex $\mathrm{I}^{127}$ as well as future measures as set out in Annex II. ${ }^{128}$ CETA also has an Annex III regarding the financial services sector in Canada. For instance, countries reserved the right to intervene in the residential housing market. ${ }^{129}$ For New Zealand, non-conforming measures include its cultural heritage, social services, water, as well as the foreshore and seabed. ${ }^{130}$

\section{Right to Regulate}

An attempt to preserve sovereignty can be seen in the emphasis of the States' right to regulate in mega-regionals. This approach may have been inspired by Recital 4 of the Preamble to GATS, which recognizes 'the right of Members to regulate, and to introduce new regulations, on the supply of services within their territories in order to meet national policy objectives.' The Appellate Body clarified in China - Publications and Audiovisual Products that 'the right to regulate' in the WTO encompasses (1) the power to take regulatory action that does not infringe the covered agreements and (2) the power to take regulatory action that derogates from the covered agreements but can be justified under an exception clause. ${ }^{131}$

\section{a. Right to Regulate in the TPP}

Recital 9 of the Preamble to the TPP underscores national sovereignty as enshrined in the 'inherent right to regulate.' As the legal effect of the Preamble is limited, ${ }^{132}$ the framers elaborated that right, for instance, in the Investment as well as the Exceptions and General Provisions Chapters. Also, the right to regulate is buttressed by the right to exercise discretion with regard to the allocation of resources in the Chapters on Labour ${ }^{133}$ and the Environment. ${ }^{134}$ One of the provisions of the Agreement that reflects the Parties' right to regulate is Art. 9.16:

Nothing in this Chapter shall be construed to prevent a Party from adopting, maintaining or enforcing any measure otherwise consistent with this Chapter that it considers appropriate to ensure that investment activity in its territory is undertaken in a manner sensitive to environmental, health or other regulatory objectives.

Just like Art. 1114 (1) NAFTA, Art. 9.16 TPP does not constitute a fully-fledged exception clause by reason of the limitation 'otherwise consistent.' Consequently, no inconsistencies could be justified, no investors' rights be overridden on that basis. Its legal effect is that it puts

127 Arts. 9.12.1, 10.7.1 TPP; Arts. 8.15.1, 13.10.1 and 2 CETA.

128 Arts. 9.12.2, 10.7.2 TPP; Arts. 8.15.2, 13.10.3 CETA.

129 For the TPP, see Annex II New Zealand 32; Annex II Canada 3.

130 See Report on the Trans-Pacific Partnership Agreement (Waitangi Tribunal 2016) 51.

131 WTO China - Measures Affecting Trading Rights and Distribution Services for Certain Publications and Audiovisual Entertainment Products - Report of the Appellate Body (19 January 2010) WT/DS363/AB/R, 228.

132 Art. 31 (2) Vienna Convention.

133 Art. 19.5.2 TPP, second sentence.

134 Arts. 20.3.5, 20.17.6 TPP. Note that other chapters of the TPP are relevant to the investment chapter by virtue of Art. 9.3.1. 
beyond dispute that particular policy objectives (environment, health) are legitimate. This is of significance for the interpretation of, for example, 'fair and equitable treatment' within the meaning of Art. 9.6 TPP. In light of Art. 31 (2) Vienna Convention, however, Art. 9.16 TPP does not add anything to preambular para. 9 in terms of normative content, certainly not additional policy space.

\section{b. Right to Regulate in CETA}

The similar provision in CETA, Art. 8.9.1, does not contain the same limitation in the wording. Still, it states the obvious, as the mentioned policy fields have not been subjected to harmonized standards by CETA. The issue is to what extent the provisions and disciplines under a megaregional restrict the right to regulate. Art. 23.2 CETA and Art. 19.5.2 TPP exemplify this for the area of labour law. On the one hand, they reaffirm the right to regulate. This comprises the right to set priorities, to determine the level of protection, and to modify the laws. It also includes the discretionary power to allocate resources. On the other hand, the Articles make clear that the right to regulate ends where the international obligation begins. The same holds true for environmental law. ${ }^{135}$ The Joint Interpretative Instrument elaborates that. ${ }^{136}$

\section{c. Right to Regulate in TTIP}

Another example is Art. 2.1 of the TTIP investment chapter, as proposed by the European Union: ${ }^{137}$

The provisions of this section shall not affect the right of the Parties to regulate within their territories through measures necessary to achieve legitimate policy objectives, such as the protection of public health, safety, environment or public morals, social or consumer protection or promotion and protection of cultural diversity.

It is questionable, however, whether the chosen formulation would be capable of actually achieving that goal. First of all, it should be noted that the proposed text does not contain an express limitation, which only guarantees the right to regulate through measures 'otherwise consistent.' So could measures inconsistent with the investment chapter in TTIP be upheld by the contracting parties? In other words, does Art. 2.1 (Investment) TTIP provide a real exception clause along the lines of Art. XX GATT/Art. XIV GATS or does it merely confirm the policy space that the contracting parties have in any event?

The European Court of Human Rights has interpreted a similar formulation in the ECHR ('the right of a State to enforce such laws as it deems necessary' in Art. 1 (2) Protocol) as an exception clause. ${ }^{138}$ The concept of 'margin of appreciation' employed by the European Court of Human Rights is equivalent to the concept of 'policy space' used in the WTO. ${ }^{139}$ This would

\footnotetext{
135 Arts. 20.3.2 and 5, 20.17.6 TPP; Art. 24.3 CETA.

136 Available at http://www.international.gc.ca/trade-commerce/trade-agreements-accords-commerciaux/agracc/ceta-aecg/index.aspx?lang=eng (accessed 27 March 2017).

137 Available at http://trade.ec.europa.eu/doclib/docs/2015/november/tradoc_153955.pdf (accessed 27 March 2017).

138 Mellacher v Austria, Application nos 10522/83, 11011/84, 11070/84 (19 December 1989) 45, 53.

139 WTO China - Measures Related to the Exportation of Rare Earths, Tungsten, and Molybdenum - Report of the Panel (2 September 2014) WT/DS431/R, WT/DS431/R/Add.1, WT/DS432/R, WT/DS432/R/Add.1, WT/DS433/R, WT/DS433/R/Add.1, 7.137.
} 
mean that States could expropriate on that basis without having to pay compensation or they could justify a violation of the FET standard on grounds of environmental protection, public health or other legitimate policy objectives listed in Art. 2.1. Importantly, the list of objectives recognized as legitimate is not exhaustive. Following that, the level of investor protection in TTIP would remain below the customary minimum standard. It is beyond doubt that countries may derogate from customary international law. Hence, the TTIP would constitute lex specialis vis-à-vis the customary minimum standard.

What might speak in favour of an exception clause is the fact that Art. 2.1 (Investment) TTIP is phrased quite differently from, e.g., the second sentence of Art. 2.2 WTO Agreement on Technical Barriers to Trade (TBT Agreement). ${ }^{140}$ With regard to this provision, the Appellate Body clarified that the reference to a 'legitimate objective' establishes an additional requirement which a measure must fulfil for it to be WTO-consistent, not an exception. ${ }^{141}$ Nevertheless, it is not apparent from reading the text of Art. 2.1 (Investment) TTIP that the right to regulate trumps the provisions of the investment section. It merely states that this section 'shall not affect' that right. The right to regulate has always been acknowledged. In China - Publications and Audiovisual Products, the Appellate Body stressed that the 'right to regulate' constitutes 'an inherent power enjoyed by a Member's government, rather than a right bestowed by international treaties.' ${ }^{142}$ That is, an investment tribunal might read Art. 2.1 as an affirmation of existing case law and not, as desired, a norm ensuring additional policy space for democratic legislatures. Art. 8.9.1 CETA is even couched that way ('the Parties reaffirm their right to regulate').

\section{Regulatory Cooperation}

Regulatory cooperation can be distinguished from other forms of international cooperation, because it is more intrusive from a national perspective. It concerns harmonization behind borders with a view to reducing compliance costs. The chapters on regulatory cooperation in mega-regionals provide for the further development of these agreements and on this account are hugely controversial. The issue is whether that further development will occur outside the control of national parliaments.

International cooperation presupposes that governments have some latitude to make decisions. International law recognizes that. According to Art. 11 Vienna Convention, the involvement of the legislature is not always required to express consent to be bound by a treaty. CETA, for instance, does not need to be ratified by the Canadian parliament. ${ }^{143}$ In WTO law it is accepted that 'subsequent agreement' within the meaning of Art. 31 (3) (a) Vienna Convention can be a committee decision by the WTO Membership. ${ }^{144}$ Gardiner confirms that

${ }^{140}$ WTO Agreement on Technical Barriers to Trade (signed 15 April 1994, entered into force 1 January 1995) 1868 UNTS 120.

141 WTO United States - Measures Concerning the Importation, Marketing and Sale of Tuna and Tuna Products - Report of the Appellate Body (13 June 2012) WT/DS381/AB/R, 318.

142 WTO China - Publications and Audiovisual Products - Report of the Appellate Body 222.

${ }^{143}$ L. Barnett, Canada's Approach to the Treaty-Making Process (Parliament of Canada 6 November 2012) 3.3.1, available at www.parl.gc.ca/Default.aspx?Language=E (accessed 27 March 2017).

${ }^{144}$ WTO United States - Measures Concerning the Importation, Marketing and Sale of Tuna and Tuna Products - Report of the Appellate Body (13 June 2012) WT/DS381/AB/R, 372. 
a subsequent agreement does not need to 'have the same formal status as the instrument which is interpreted. ${ }^{145}$

So what is the national law perspective? Regularly, the competences exercised by regulatory bodies would have been delegated to (administrative) authorities in national systems, that is, would have left the province of the legislature in any event (e.g., through enabling clauses). The determination of contact points would be an innocuous example.

It is common practice that national lawmakers set the general legal framework and leave it to administrative authorities to flesh out and implement statutory acts. The reasons for doing so are manifold: flexibility required to find a just solution, lack of expertise, to keep the act relevant and up to date. This last reason is true of mega-regionals as well and propelled the inclusion of provisions on regulatory cooperation.

To pass constitutional muster, regulatory cooperation must not be unfettered. This raises the question of the terms of reference of regulatory bodies. What, if any, are their limitations? As a preliminary point, it should be noted that, as seen, authoritative interpretations issued by regulatory bodies, e.g. regarding the investment chapter, actually serve to preserve national autonomy, as they rein in the discretion of investment tribunals. According to Art. 30.2.2, first sentence, CETA, 'the CETA Joint Committee may decide to amend the protocols and annexes of this Agreement.' However, the fourth sentence rules out this procedure for sensitive policy fields:

amendments to Annexes I, II and III and to amendments to the annexes of Chapters Eight (Investment), Nine (Cross-Border Trade in Services), Ten (Temporary Entry and Stay of Natural Persons for Business Purposes) and Thirteen (Financial Services), except for Annex 10-A (List of Contact Points of the Member States of the European Union).

Significant changes still need to be approved by national legislatures. ${ }^{146}$

As for the TPP, Art. 25.1 makes clear that 'regulatory coherence' is limited to measures 'adopted by regulatory agencies.' This excludes measures enacted by legislatures. Thus, the policy space of national lawmakers is not interfered with. The TPP only seeks to harmonize measures which national legislatures have mandated regulatory agencies, i.e. the executive, to adopt. The same is true of CETA, where Art. 21.1 confines the scope of the chapter on regulatory cooperation 'to the development, review and methodological aspects of regulatory measures of the Parties' regulatory authorities.' The consensus principle as practiced in the regulatory cooperation bodies ${ }^{147}$ additionally safeguards national autonomy. Binding decisions cannot be made against the will of a State. This is in line with the international law model to assure legitimacy through consent. ${ }^{148}$ The Joint Interpretative Instrument affirms that

regulatory authorities can cooperate on a voluntary basis but do not have an obligation to do so, or to apply the outcome of their cooperation. ${ }^{149}$

\footnotetext{
145 R. Gardiner, Treaty Interpretation (OUP 2015) 247.

146 Art. 30.2 TPP, Art. 30.2 CETA.

147 Art. 27.3.1 TPP; Art. 26.3.3 in conjunction with Art. 26.2.1 (h) CETA.

148 D.K. Anton, P. Mathew and W. Morgan, International Law: Cases and Materials (OUP 2005) 8-9; M.N. Shaw, International Law (CUP 2014) 44.

149 Point 3 in relation to Art. 21.2.6 CETA.
} 


\section{Exceptions}

The primary place where policy space is ensured is in the exception clauses, with the general exceptions being the broadest in scope. This is where the degree of surrender of sovereignty is ultimately decided. ${ }^{150}$ In other words, exceptions actually realize the aforementioned right to regulate.

\section{a. General Exceptions}

Mega-regionals build on the WTO acquis and incorporate the general exceptions Art. XX GATT and Art. XIV GATS, ${ }^{151}$ including the relevant case law. ${ }^{152}$ Members may act inconsistently with mega-regionals for the sake of competing interests. This methodology is not free from doubt because it makes trade liberalization the rule and other societal values and interests the exception, requiring justification. ${ }^{153}$ However, the Appellate Body has alleviated this concern to some extent by clarifying in $U S$ - Gasoline and EC-Hormones that exceptions are not to be interpreted narrowly as a rule. ${ }^{154}$ This would only be the case if the WTO agreements pursued one predominant objective, which they do not according to their preambles. ${ }^{155}$ Rather, exception clauses are the place where conflicting societal interests are weighed up, commensurate with the principle of proportionality, with a view to optimizing the realization of the interests at stake. ${ }^{156}$

\section{i. Scope}

Another issue remains. The catalogue of protected interests in the general exceptions in the WTO is exhaustive and cannot be extended by way of interpretation. The way out in WTO law is to request a waiver, which only provides a temporary remedy. ${ }^{157}$ Thus, mega-regionals import a problem that also challenged EU primary law. In principle, societal values and interests can be taken into account at two stages: in the delineation of the scope of (1) the substantive rights and obligations and/or (2) exception clauses. ${ }^{158}$

${ }^{150}$ See WTO European Communities - Measures Prohibiting the Importation and Marketing of Seal Products Report of the Appellate Body (18 June 2014) WT/DS400/AB/R, WT/DS401/AB/R, 5.125.

151 Art. 29.1 TPP, Art. 28.3 CETA. Note that Art. 28.3.2 CETA paraphrases Art. XIV GATS.

152 Art. 28.12.3 TPP, second sentence; Art. 29.17 CETA, second sentence.

153 Trebilcock, Howse and Eliason, The Regulation of International Trade 163. See also WTO European Communities - Measures Affecting Asbestos and Asbestos-containing Products - Report of the Appellate Body (5 April 2001) WT/DS135/AB/R, 154 (Concurring Opinion); C. Riffel, 'Human Rights Protection in the AsiaPacific: What will be the Role of the TPP?' (2016) 15 Otago Law Review 339, , 348-349.

${ }^{154}$ WTO United States - Standards for Reformulated and Conventional Gasoline - Report of the Appellate Body (20 May 1996) WT/DS2/AB/R, 18; WTO EC Measures Concerning Meat and Meat Products (Hormones) Report of the Appellate Body (13 February 1998) WT/DS26/AB/R, WT/DS48/AB/R, 104.

155 See, e.g., Recital 1 of the Preamble to the WTO Agreement.

156 WTO United States - Import Prohibition of Certain Shrimp and Shrimp Products - Report of the Appellate Body (6 November 1998) WT/DS58/AB/R, 159; WTO European Communities - Conditions for the Granting of Tariff Preferences to Developing Countries - Report of the Appellate Body (20 April 2004) WT/DS246/AB/R, 94-95.

157 Art. IX WTO Agreement.

${ }^{158} \mathrm{Cf}$. A. Keene, 'The Incorporation and Interpretation of WTO-Style Environmental Exceptions in International Investment Agreements’ (2017) 18 Journal of World Investment \& Trade 62, 86ff. 
In Cassis de Dijon, the European Court of Justice (ECJ) developed the doctrine of mandatory requirements. ${ }^{159}$ This became necessary after the Court had successively expanded the scope of the fundamental freedoms from a prohibition of discrimination to a prohibition of restrictions. ${ }^{160}$ The exception clauses provided for in the TFEU ${ }^{161}$ are consequently too narrow to do justice to the legitimate concern of the EU Member States to regulate domestic matters in the public interest, given that the lists of recognized public welfare goals, able to justify infringements of the TFEU, are closed ones. ${ }^{162}$ The solution found by the ECJ was to read important societal values and interests that may conflict with the policy objective of an internal market in a particular case into the fundamental freedoms as inherent limitations. Since Cassis de Dijon, this has become settled case law of the ECJ, as enunciated in a recent decision regarding the free movement of goods:

[O]bstacles to the free movement of goods which are the consequence of applying, to goods coming from other Member States where they are lawfully manufactured and marked, rules that lay down requirements to be met by such goods constitute measures having equivalent effect prohibited by Art. 34 TFEU. This is so even if those rules apply without distinction to all products unless their application can be justified by a public-interest objective taking precedence over the free movement of goods. ${ }^{163}$

The Appellate Body paved the way for a similar development in WTO law in ECAsbestos. ${ }^{164}$ In that case, the national treatment obligation, Art. III:4 GATT, was at issue and the question what legal implications the health risks associated with asbestos have. The Appellate Body noted that 'evidence relating to the health risks associated with a product may be pertinent in an examination of "likeness". ${ }^{165}$ In the same vein, the panel in Canada - Wheat Exports and Grain Imports observed that 'different treatment' is not tantamount to 'less favourable treatment,' as 'there may be legitimate reasons for Canada to treat domestic grain and like imported grain differently, for example, because the latter has not been subjected to the Canadian quality assurance system. ${ }^{166}$ Furthermore, the Appellate Body held in $E C$ Asbestos that 'a Member may draw distinctions between products which have been found to be "like", without, for this reason alone, according to the group of "like" imported products "less favourable treatment" than that accorded to the group of "like" domestic products. ${ }^{167}$ In principle, societal values and interests could be taken into account in the likeness test or the

\footnotetext{
159 Case 120/78 Rewe-Zentral AG v Bundesmonopolverwaltung für Branntwein [1979] ECR 649.

160 W. Frenz, Europarecht (Springer 2015) 82.

161 Arts. 36, 45 (3), 52 (1), 65.

${ }^{162}$ E. Neumayer, 'Greening the WTO Agreements: Can the Treaty Establishing the European Community be of Guidance?’ (2001) 35 Journal of World Trade 145, 150.

163 Case C-481/12 UAB 'Juvelta' v VI 'Lietuvos prabavimo rūmai' (16 January 2014) 17.

164 WTO European Communities - Measures Affecting Asbestos and Asbestos Containing Products - Report of the Appellate Body WT/DS135/AB/R (5 April 2001).

165 Ibid., 113.

166 WTO Canada - Measures Relating to Exports of Wheat and Treatment of Imported Grain - Report of the Panel WT/DS276/R (27 September 2004), upheld by Appellate Body WT/DS276/AB/R, 6.209.

167 WTO European Communities - Measures Affecting Asbestos and Asbestos Containing Products - Report of the Appellate Body WT/DS135/AB/R 100 (emphasis in original).
} 
'less favourable treatment' element. ${ }^{168}$ As to the latter, the Appellate Body dealt a blow to this line of argument in EC - Seal Products. ${ }^{169}$ This is where the analyses under Art. III:4 GATT and Art. 2.1 TBT Agreement differ: the Appellate Body reads the legitimate objectives set forth in the Preamble to the TBT Agreement, i.e. what would be discussed under an exception clause in GATT, into Art. 2.1. ${ }^{170}$

The same questions will arise under mega-regionals and will call for answers. The TPP confirms the approach of the Appellate Body with respect to the non-discrimination principle in the investment chapter:

For greater certainty, whether treatment is accorded in 'like circumstances' under Art. 9.4 (National Treatment) or Art. 9.5 (Most-Favoured-Nation Treatment) depends on the totality of the circumstances, including whether the relevant treatment distinguishes between investors or investments on the basis of legitimate public welfare objectives. ${ }^{171}$

\section{ii. Interplay between Exceptions and Rights and Obligations}

The aforementioned case law is indicative of an interplay between the scope of exceptions, on the one hand, and the scope of rights and obligations, on the other hand. The broader the scope of the exceptions, the more broadly the scope of the rights and obligations can be interpreted. In other words, the breadth of the substantive rights and obligations must be matched by equally broad exception clauses. ${ }^{172}$ Otherwise, the adjudicating bodies would need to step in and sort out the resultant mismatch by connecting societal values and interests to particular elements of the former. ${ }^{173}$

An example from investment law illustrates this: the FET standard in Art. 10 (1) JapanKorea $\mathrm{BIT}^{174}$ is not confined to customary international law and consequently broader than the FET standard in Art. 5 (1) Trilateral Agreement between those two countries and China, which refers to the 'standard of treatment accorded in accordance with generally accepted rules of international law. ${ }^{175}$ By the same token, the Japan-Korea BIT has public health and public order exceptions in Art. 16 (1) (c) and (d), unlike the Trilateral Agreement that only contains

\footnotetext{
168 Trebilcock, Howse and Eliason, The Regulation of International Trade 164; Andersen, 'Protection of NonTrade Values in WTO Appellate Body Jurisprudence' 399-400.

169 WTO EC - Seal Products - Report of the Appellate Body 5.116. See also B. McGrady, 'Principles of NonDiscrimination after US - Clove Cigarettes, US - Tuna II, US - Cool and EC - Seal Products and their Implications for International Investment Law' (2015) 16 Journal of World Investment \& Trade 141, $144,157$.

170 WTO United States - Measures Affecting the Production and Sale of Clove Cigarettes - Report of the Appellate Body 119-120, 173-174.

171 Footnote 14.

${ }^{172}$ For CETA, see A. de Mestral, 'When Does the Exception Become the Rule? Conserving Regulatory Space under CETA' (2015) 18 Journal of International Economic Law 641, 642.

173 McGrady, 'Principles of Non-Discrimination after US - Clove Cigarettes, US - Tuna II, US - Cool and ECSeal Products and their Implications for International Investment Law' 159-161.

174 Agreement between the Government of the Republic of Korea and the Government of Japan for the Liberalisation, Promotion and Protection of Investment (signed 22 March 2002, entered into force 1 January 2003), available at http://investmentpolicyhub.unctad.org/IIA (accessed 27 March 2017).

175 Agreement among the Government of Japan, the Government of the Republic of Korea and the Government of the People's Republic of China for the Promotion, Facilitation and Protection of Investment (signed 13 May 2012, entered into force 17 May 2014).
} 
security exceptions in Art. 18 thereof. ${ }^{176}$ The same phenomenon can be found in municipal law as well. For instance, the German constitutional court interprets the basic right of human dignity in Art. 1 (1) Basic Law ${ }^{177}$ narrowly and only subsumes the 'core of personality' thereunder, because the German Constitution does not allow any deviation from the inviolability of this prescription. ${ }^{178}$

\section{iii. Assessment}

In the final analysis, there is an interplay between the scope of substantive rights and obligations and the scope of exception clauses: both must match. This is something to keep in mind when interpreting and applying mega-regionals in the future. Their rights and obligations must be read in light of the breadth of the exception clauses contained therein so as to ensure a proper balance between competing societal values and interests. In the following, we will examine what the implications of this rule-exception paradigm are for investors' rights.

\section{b. Exceptions and Investment}

Investment rules are disputed because they allegedly do not take sufficient account of other legitimate societal values and interests of the host State. ${ }^{179}$ CETA provides exceptions for the establishment of investments and non-discriminatory treatment in Art. 28.3.2, the general exceptions provision. By contrast, the general exceptions of the TPP as set out in Art. 29.1 do not apply to the investment chapter. Only the provision on performance requirements has a specialized exception clause in Art. 9.10.3 (d) and (h). From this it follows that violations of the international minimum standard of treatment or the right to compensation in the event of expropriation can only be justified on the basis of customary international law. This raises the question of whether customary international law can serve as a defence to claims under megaregionals. The prevailing view seems to reject that as far as trade disputes are concerned, ${ }^{180}$ whereas in investment disputes it is commonplace. The governing law is not limited to the agreement but also includes other rules of international law that are applicable. ${ }^{181}$ By incorporating customary international law standards into the agreements, ${ }^{182}$ the parties also incorporate, by implication, concomitant limitations and exceptions, i.e. force majeure and the doctrine of necessity as laid down in the Articles on State Responsibility. ${ }^{183}$ Following the above argumentation, the scope of those rights and obligations must be narrowly delineated, as limited exceptions suggest to interpret substantive rights and obligations narrowly.

\footnotetext{
176 Alschner, 'Regionalism and Overlap in Investment Treaty Law: Towards Consolidation or Contradiction?' 288.

177 'Human dignity shall be inviolable. To respect and protect it shall be the duty of all State authority.'

178 See, e.g., BVerfGE, Order of the First Chamber of the First Senate of 6 September 2000, 1 BvR 1056/95, 37.

179 Lester, 'Rethinking the International Investment Law System' 217.

180 See, e.g., P. Van den Bossche and W. Zdouc, The Law and Policy of the World Trade Organization (CUP 2013) 63.

181 Art. 9.25.1 and 2 (b) (ii) TPP, Art. 8.31.1 CETA.

182 See Annex 9-A TPP.

183 Arts. 23 and 25.
} 


\section{c. Definition of Indirect Expropriation}

The concept of 'indirect expropriation' is worth mentioning in this context. It ensures that States cannot circumvent their obligation to compensate foreign investors that have been deprived of their possessions but left their title proforma. Having said that, this taking must be equivalent to expropriation. The government action must amount to an expropriation with the only exception of the formal title remaining untouched. Anything less, e.g. a mere reduction in value of the investment, would not qualify as an indirect expropriation. Para. 3 (b) Annex 9-B to the TPP clarifies that

Non-discriminatory regulatory actions by a Party that are designed and applied to protect legitimate public welfare objectives, such as public health, safety and the environment, do not constitute indirect expropriations, except in rare circumstances.

In light of its wording ('except in rare circumstances'), the provision falls short of an exception clause. However, it is more than just window dressing. The phrase 'in rare circumstances' provides a guideline for treaty interpreters to interpret the requirements of indirect expropriation restrictively as far as health measures, environmental measures, etc. are concerned. The same holds true for para. 3 Annex 8-A (Expropriation) to CETA.

Moreover, CETA makes certain in Art. 8.12.6 that 'the revocation, limitation or creation of intellectual property rights, to the extent that these measures are consistent with the TRIPS Agreement and Chapter Twenty (Intellectual Property), do not constitute expropriation.' It further lays down, in the second sentence, that a mere violation of international IP obligations 'does not establish an expropriation.' This provision is a legislative response to the Eli Lilly case. ${ }^{184}$

\section{d. Treaty of Waitangi Exception}

One of the most astounding provisions in the TPP is Art. 29.6, the Treaty of Waitangi exception. It gives New Zealand a blanket provision to deviate from the TPP and, for instance, to run affirmative action programmes for the benefit of its indigenous population. By the same token, it deprives the New Zealand government of the otherwise possible argument that it cannot implement a particular obligation under the Treaty of Waitangi because it would be at odds with its international obligations. The Treaty of Waitangi establishes a special partnership between the Crown and the Māori, New Zealand's indigenous people. Among other things, it obliges the New Zealand government to actively protect Māori interests. ${ }^{185}$

\section{i. Broad Scope}

The Treaty of Waitangi exception is remarkable for its broad scope. Whereas other TPP signatories with an indigenous population rely on annex exemptions, such as Australia, ${ }^{186}$

\footnotetext{
${ }^{184}$ Eli Lilly v. Canada (Final Award) (16 March 2017) ICSID Case No UNCT/14/2.

185 New Zealand Government, 'Story: Principles of the Treaty of Waitangi' (The Encyclopedia of New Zealand), available at www.teara.govt.nz/en/principles-of-the-treaty-of-waitangi-nga-matapono-o-te-tiriti (accessed 27 March 2017).

186 Annex II 3, Annex IV.
} 
Peru, ${ }^{187}$ or Chile, ${ }^{188}$ the scope of Art. 29.6 is not confined to investment and trade in services but applies to all chapters ('nothing in this Agreement'). Furthermore, New Zealand may 'accord more favourable treatment to Maori' regardless of whether this is called for under the Treaty of Waitangi ('including'). The title of the provision ('Treaty of Waitangi') does not amount to a limitation of the scope to Treaty obligations. It is clear from the objective of the TPP to establish equal conditions of competition between the TPP Members ${ }^{189}$ that the more favourable treatment is in relation to foreign traders and investors. ${ }^{190}$ Art. 29.6 TPP thus provides a defence against an infringement of the national treatment obligations in the TPP. ${ }^{191}$ On a related note, other measures which the New Zealand government may adopt to put the Treaty of Waitangi into effect but which are outside the remit of the TPP do not require justification under the TPP ('in respect of matters covered by this Agreement'). ${ }^{192}$

Normally, the TPP would take precedence over a Member's internal law from an international law perspective. Not even the constitution of a country can be used as an excuse for non-compliance according to Art. 27 Vienna Convention. Art. 29.6.1 TPP reverses that precept. What is more, the clause is self-judging ('deems') and the exercise of discretion on the part of New Zealand is non-actionable pursuant to para. 2 thereof. Whether a particular government measure actually improves the situation of Māori can therefore not be challenged before a TPP panel. A panel could 'only' find an inconsistency of that measure with the TPP, but no violation, because the New Zealand measure would be justified pursuant to para. 1 . That is, a panel could not attach any legal consequences to the found inconsistency, notably not force New Zealand to withdraw the inconsistent measure. ${ }^{193}$

Inconsistency, i.e. whether an infringement occurred, is only the first step in the legal analysis, the second step being whether the infringement is justifiable under an exception clause. Consequently, by stipulating that 'A panel ... may be requested to determine only whether any measure referred to in paragraph 1 is inconsistent with a Party's rights under this Agreement,' Art. 29.6.2, third sentence, TPP states the obvious, namely that 'nothing in this Agreement shall preclude the adoption by New Zealand of measures.' The third sentence of para. 2 does not add anything that would not already flow from para. 1. Other exceptions dispense with this clarification. For instance, Art. XIV GATS merely provides that 'nothing in this Agreement shall be construed to prevent the adoption or enforcement by any Member of measures.' All the legal effects of an exception clause are encapsulated in that phrase.

From a New Zealand point of view, it is important that the TPP does not prejudge the nature and legal status of the Treaty of Waitangi in the New Zealand legal order. What obligations there are under the Treaty is not subject to scrutiny. ${ }^{194}$ A TPP panel would only consider national law 'as evidence of compliance or non-compliance with international obligations'

\footnotetext{
187 Annex II 4, Annex IV 2.

188 Annex II 7, Annex IV 7.

189 See, e.g., the reference to 'a level playing field' in Recital 11 of the Preamble.

190 This was disputed in Report on the Trans-Pacific Partnership Agreement (Waitangi Tribunal 2016$) 37$.

191 See, e.g., Arts. 2.3, 9.4, 10.3, 18.8 TPP. See also A. Kawharu, 'Process, Politics and the Politics of Process: The Trans-Pacific Partnership in New Zealand' (2016) 17 Melbourne Journal of International Law 286, 304306.

192 See Report on the Trans-Pacific Partnership Agreement (Waitangi Tribunal 2016) 51.

193 Art. 29.6.2 TPP, third sentence.

194 Art. 29.6.2 TPP, first sentence.
} 
along the lines of the Havana Club ruling. ${ }^{195}$ Also, who identifies as Māori is an internal matter and would be outside the jurisdiction of a TPP panel. It is New Zealand law that determines what a Māori business is.

\section{ii. Abuse of Rights}

Exception clauses are limited themselves and have to be interpreted in good faith, in particular abus de droit, and in light of competing interests, notably the right to trade. This finds expression in the chapeau of Art. XX GATT and Art. XIV GATS. In German legal thinking the chapeau constitutes a Schranken-Schranke, i.e. a limitation on an exception. The Treaty of Waitangi exception clause is restricted by the introductory phrase in para. 1 :

Provided that such measures are not used as a means of arbitrary or unjustified discrimination against persons of the other Parties or as a disguised restriction on trade in goods, trade in services and investment.

This wording is inspired by the chapeau of the general WTO exceptions, which the Appellate Body read as an embodiment of the doctrine of abuse of rights. ${ }^{196}$ Although the Appellate Body made this statement only with respect to Art. XX GATT, it also holds true for Art. XIV GATS. ${ }^{197}$

The doctrine of abuse of rights is a general principle of law within the meaning of Art. 38 (1) (c) Statute of the International Court of Justice (ICJ Statute), ${ }^{198}$ derived from the tenet of good faith. ${ }^{199}$ Good faith itself constitutes a fundamental principle of international law of which States cannot contract out. ${ }^{200}$ That is, even without its inclusion, the prohibition of abuse of rights would apply in accordance with Art. 26 Vienna Convention: 'Every treaty in force ... must be performed ... in good faith.'

This raises the question in what constellations an abuse of rights might be given. Currently, the Māori population of New Zealand makes up around 15 per cent, and according to Statistics New Zealand it is growing. ${ }^{201}$ Let us assume for argument's sake that someday in the future half of the New Zealand population identifies as Māori. If, in such a situation, New Zealand used the Treaty of Waitangi exception to protect half of its economy, its trading partners would argue - and rightly so - that this is not the deal anymore they entered into, as a level playing

195 WTO United States - Section 211 Omnibus Appropriations Act of 1998 - Report of the Appellate Body (1 February 2002) WT/DS176/AB/R 105.

${ }^{196}$ WTO United States - Import Prohibition of Certain Shrimp and Shrimp Products - Report of the Appellate Body 158.

197 WTO United States - Measures Affecting the Cross Border Supply of Gambling and Betting Services - Report of the Panel (20 April 2005) WT/DS285/R, 6.581.

198 Statute of the International Court of Justice (adopted 26 June 1945, entered into force 24 October 1945) 145 BSP 832.

199 WTO United States - Import Prohibition of Certain Shrimp and Shrimp Products - Report of the Appellate Body 158; A. Kiss, 'Abuse of Rights' in R. Wolfrum and F. Lachenmann (eds), Max Planck Encyclopedia of Public International Law (OUP 2006) 35.

${ }^{200}$ M. Kotzur, 'Good Faith (Bona fide)' in R. Wolfrum and F. Lachenmann (eds), Max Planck Encyclopedia of Public International Law (OUP 2009) 22; R. Kolb, Peremptory International Law - Jus Cogens: A General Inventory (Bloomsbury Publishing 2015) 57-58.

201 Statistics New Zealand, 'How is our Māori Population Changing?' (2015), available at www.stats.govt.nz (accessed 27 March 2017). 
field is no longer given. In the author's view, this would be an example of a violation of the introductory phrase of para. 1. The Treaty of Waitangi exception clause was introduced to protect minority rights in New Zealand. Solely on that basis was it accepted by the other contracting parties.

\section{iii. Assessment}

The Treaty of Waitangi exception gives New Zealand ample discretion to favour Māori businesses. In fact, it places New Zealand (constitutional) law above the TPP. That New Zealand's trading partners have accepted such a broad exception clause in favour of one party can only be explained by the fact that New Zealand has never abused such clauses in its other FTAs and because of its clean sheet towards foreign businesses and investors. ${ }^{202}$

There is no exception in the WTO agreements specifically favouring indigenous peoples. That is, under WTO law, New Zealand has no recourse to a Treaty of Waitangi defence. However, it included a provision to the same effect in the national treatment column of its GATS Schedule: with regard to all four modes of supply, New Zealand is

Unbound for current and future measures at the central and sub-central levels according more favourable treatment to any Maori person or organisation in relation to the acquisition, establishment or operation of any commercial or industrial undertaking. ${ }^{203}$

As a horizontal commitment, it applies to all service sectors covered. In conclusion, New Zealand is free to favour Māori service providers, but not producers of goods, without violating the WTO national treatment obligation.

\section{Remedies}

One cannot assess the intrusion of a mega-regional into the national legal order without having regard to the clout of its enforcement mechanism. This concerns the question of available remedies. Here again, one has to distinguish between trade and investment disputes.

\section{a. Trade Disputes}

Non-compliance with trade rules comes with considerable costs for the perpetrating State in the form of suspended concessions, i.e. legalized trade barriers. Nevertheless, the respondent has the opportunity to pay compensation and maintain the inconsistent measure. Although billed as 'temporary, ${ }^{204}$ this can be a very long period of time, as the WTO case EC Hormones illustrates. ${ }^{205}$

When the WTO has authorized the suspension of concessions under the DSU, it is questionable whether, by making use of the authorization, the suspending State violates an

202 See S. Lester, Will Someone Please File a WTO Complaint against New Zealand? (IELP Blog 12 February 2016), available at http://worldtradelaw.typepad.com (accessed 27 March 2017).

203 New Zealand, GATS Schedule of Specific Commitments, GATS/SC/62 (15 April 1994) 6.

204 Art. 28.20.15 TPP, Art. 29.14 CETA.

205 For an overview, see World Trade Organization, European Communities - Measures Concerning Meat and Meat Products (Hormones), available at www.wto.org/english/tratop_e/dispu_e/cases_e/ds26_e.htm (accessed 27 March 2017). 
existing FTA between the parties to the dispute. Conversely, when a party suspends benefits under an FTA, the question arises whether, in doing so, it violates the WTO Agreement.

The general international law stance is that, in terms of hierarchy of norms, all treaties, WTO Agreement and FTAs, are at the same level. The WTO, however, claims an elevated position: It checks whether FTAs are in conformity with its own rules. ${ }^{206}$ Its dispute settlement mechanism is exclusive commensurate with Art. 23 DSU. The WTO system thus appears to be a kind of universal 'trade constitution.' This is the WTO perspective. The issue is how other trading regimes respond to that.

First of all, it should be recalled that, under both the TPP and CETA, the contracting parties reaffirm their rights and obligations they have under the WTO Agreement. ${ }^{207}$ In line with this, CETA clarifies in Art. 29.3.4, first sentence, that 'Nothing in this Agreement shall preclude a Party from implementing the suspension of obligations authorised by the WTO Dispute Settlement Body.' A provision to the same effect can be found in Art. 29.1.4 TPP. As to the reverse case, i.e. when obligations under a mega-regional are suspended, Art. 29.3.4, second sentence, CETA provides that 'A Party may not invoke the WTO Agreement to preclude the other Party from suspending obligations pursuant to this Chapter.' A regulation along the same lines is lacking in the TPP. Here, the fork-in-the-road clause, Art. 28.4.2, comes into play, stipulating a pactum de non petendo regarding the suspension of the TPP.

\section{b. Investment Disputes}

From a host State's perspective, the worst case scenario in an investment dispute would be if the State had to compensate a foreign investor. But it would be under no obligation to change its domestic law, for remedies are limited to monetary damages and restitution of property ('only'), plus legal costs; no punitive damages are awarded. ${ }^{208}$ Art. 8.31.2 CETA expressly stipulates that 'The Tribunal shall not have jurisdiction to determine the legality of a measure, alleged to constitute a breach of this Agreement, under the domestic law of the disputing Party.'

Still, it is feared that the looming duty to pay compensation, hanging over the heads of national lawmakers like the sword of Damocles, leads to a regulatory chill in policy areas of societal importance such as health or the environment. ${ }^{209}$ The delay of plain packaging legislation in New Zealand is a case in point.

Let us be clear: regulatory chill is an issue because ISDS is so effective. In the author's view, the solution lies in the framers defining 'loss' in a restrictive way, not in the outright rejection of ISDS. To rein in ISDS, a jurisdictional carve-out seems arbitrary. The negotiators might miss some sensitive measures or, on the other extreme, they limit the jurisdiction to an extent that would completely undermine locus standi. How can it be justified to exclude tobacco control measures in the TPP but not other measures pursuing an equally important public welfare goal? What about other threats to health such as sugary or junk food? As seen, neither will a 'right to regulate' yield the desired outcome unless it is designed as a proper exception clause. When it comes to the crunch, a right to regulate could not justify a derogation from existing international law obligations.

\footnotetext{
206 Art. XXIV GATT, Art. V GATS, Enabling Clause.

207 Art. 1.2.1 (a) TPP, Art. 1.5 CETA.

208 Art. 9.29 TPP, Art. 8.39 CETA.

209 Report on the Trans-Pacific Partnership Agreement (Waitangi Tribunal 2016) 41.
} 
What causes the regulatory chill is the obligation under Art. 36 (2) Articles on State Responsibility to compensate for lost profits. The article reads as follows: 'The compensation shall cover any financially assessable damage including loss of profits insofar as it is established.' What the parties, therefore, could do to take away the edge off ISDS is to contract out of that obligation and provide panels with guidance as to the calculation of damages.

There are different ways to calculate damages depending on the loss suffered. All in all, three types of losses can be distinguished: restitution loss, reliance loss, and expectation loss. ${ }^{210}$ Expectation loss is the loss of the bargain. ${ }^{211}$ Compensation in this case comprises the receipt of the promised performance. ${ }^{212}$ This includes lost profits. ${ }^{213}$ Whereas restitution and reliance loss constitute actual losses, the innocent party, under the head of 'expectation loss,' receives something that it hoped to get but never had. ${ }^{214}$ Consequently, the rationale for compensating expectation loss is less compelling. ${ }^{215}$

Given the way Art. 36 (2) Articles on State Responsibility is phrased, it is applicable not only when another State is the complaining party but also to ISDS. Accordingly, damages consequent on a violation of investors' rights are recoverable. This is the case regardless of whether the investors' rights are derived from an investment contract or a treaty. Nevertheless, the Articles on State Responsibility merely reflect customary international law, ${ }^{216}$ which means that States can contract out of this obligation to pay for loss of profits. ${ }^{217}$ They could issue an authoritative interpretation ${ }^{218}$ explicitly limiting an investment award to compensation for accrued losses, by clarifying that 'loss' within the meaning of the respective agreement ${ }^{219}$ refers to loss of the investment, not loss of profits. This would confine investment claims to actual losses, e.g. the investor's expenditures, with the consequence that if foreign investors wanted to recover their lost profits, they would have to fall back on national courts. Such clarification by the parties would be a potent tool to control the budgetary implications of investment disputes, while preserving ISDS. Should an investment treaty demand the exhaustion of local remedies, this bifurcation of remedies would not even prolong the proceedings.

210 H. McGregor, McGregor on Damages (Sweet \& Maxwell 2014) 4-036.

211 E. Peel, Treitel on The Law of Contract (Swett \& Maxwell 2015) 20-022; High Court of Auckland, Newmans Tours Ltd v Ranier Investments Ltd (1992) 2 New Zealand Law Reports 68, 86.

212 J.W. Carter and J. Ren, Carter's Guide to New Zealand Contract Law (2016) 396.

${ }^{213}$ For German law, see s 252 German Civil Code. For the common law, see S. Macaulay et al., Contracts: Law in Action vol. 1 The Introductory Course (LexisNexis 2010) 113; McGregor, McGregor on Damages 10-033ff; WL Thompson Ltd v Robinson (Gunmakers) Ltd [1955] Chancery Division 177, 183, [1955] 1 All England Reports $154,157$.

214 S. Todd, 'Remedies' in J. Burrows, J. Finn and S. Todd (eds), Law of Contract in New Zealand (LexisNexis 2016) 791.

215 L.L. Fuller and W.R. Perdue, 'The Reliance Interest in Contract Damages: 1' (1936) 46 The Yale Law Journal $52,53$.

216 J.R. Crawford, 'State Responsibility' in R. Wolfrum and F. Lachenmann (eds), Max Planck Encyclopedia of Public International Law (OUP 2006) 31, 65.

217 Art. 55 Articles on State Responsibility.

218 Arts. 9.25.3, 27.2.2 (f) TPP; Arts. 8.31.3, 8.44.3 (a) CETA.

219 Art. 9.29.2 TPP, Art. 8.39.3 CETA. 


\section{Withdrawal}

Finally, as a last resort, States can withdraw from a mega-regional they previously joined in accordance with Art. 54 (a) Vienna Convention, with all the economic costs that this step entails. $^{220}$ The looming Brexit from the European Union shows that this is no longer a hypothetical scenario.

\section{Conclusion}

A court or tribunal derives its authority from the legal instrument creating it: for a constitutional court, this would be the constitution; for an administrative court, a national act; for the International Court of Justice, the UN Charter. Thus, the legitimacy crisis of, in particular, investment tribunals is tantamount to a crisis of the underlying legal instruments. This crisis is fuelled by a fear of competence shift away from national parliaments towards the international realm. People do not vote on international rules; the law-making procedure is mediated through the State governments. ${ }^{221}$

Cottier stresses that 'Legitimacy depends upon underlying values. ${ }^{\text {,22 }}$ When negotiating FTAs, notably mega-regionals, culture and shared values matter. So does the political dimension of those agreements. Governments tend to prioritize FTAs with friendly governments with which they already have a robust trade relationship. Common values can smooth the way politically, but not always, as the headwind against CETA and TTIP demonstrates. The birth pangs of these two agreements can be explained by the fact that there is not one hegemonic party that could foist its model on the other party. ${ }^{223}$ As a result, the agreements are likely to lead to changes in the legal orders on both sides. Considering the size of the participating economies, the positive as well as negative effects will be palpable.

According to modern understanding, human rights are not only political rights but also include economic rights. ${ }^{224}$ International trade and investment law realizes economic freedom across borders. ${ }^{25}$ Otherwise, the right to trade and invest would be confined to a particular jurisdiction. To the extent that national sovereignty is restricted, individual economic freedom is achieved on the international plane. We can find the same conflict in national law as well: civil liberties are supposed to protect the individual from State interference, in a democracy from the rule of the majority (status negativus). ${ }^{226}$ Against this backdrop, sovereignty, even if backed by the demos, ought not to be treated as sacrosanct. There can be no doubt that for the world economic order to function, international cooperation is imperative, which, in turn, requires the participating States to let the exercise of their sovereignty rest to some degree. Some common rules are needed to this end.

\footnotetext{
220 Art. 30.6 TPP, Art. 30.9.1 CETA.

${ }^{221}$ Krajewski, 'Democratic Legitimacy and Constitutional Perspectives of WTO Law' 169.

222 T. Cottier, 'Multilayered Governance, Pluralism, and Moral Conflict' (2009) 16 Indiana Journal of Global Legal Studies 647, 659.

223 Cf. Gantz, 'Regional Trade Agreements' 245.

${ }^{224}$ See International Covenant on Economic, Social and Cultural Rights (adopted 16 December 1966, entered into force 3 January 1976) 993 UNTS 3.

225 See P.-T. Stoll, 'Constitutional Perspectives on International Economic Law' in M. Cremona et al. (eds), Reflections on the Constitutionalisation of International Economic Law (Martinus Nijhoff 2014) $208 \mathrm{ff}$.

${ }^{226}$ For European law, see D. Ehlers, 'General Principles' in D. Ehlers (ed), European Fundamental Rights and Freedoms (de Gruyter 2007) 33.
} 
In truth, it is about the allocation of responsibilities at the right level of governance. ${ }^{227}$ The concept of sovereignty is not helpful in that regard. Rather, which level of governance (municipal, regional, national, international) is best suited to protect societal values and interests is the fundamental question. That is, there is not only the power struggle between different branches of government (i.e., the executive, legislative, and judicial branch), but also between different layers of governance. Bearing this in mind, the debate surrounding megaregionals boils down to the proper delimitation of competences. Nationally, this task is performed by constitutional law; internationally, it is often left to adjudicators to draw the dividing line.

The misgivings about mega-regionals, in general, and ISDS, in particular, stem from a worry that the proposed agreements do not strike the right balance, with the consequence that not enough policy space is left for national legislatures. The drafters sought to preserve regulatory autonomy by building into the agreements certain safeguards. Importantly, these safeguards cannot be evaded by foreign investors importing more favourable treatment under other treaties on grounds of MFN arguments. Art. 8.7.4, second sentence, CETA provides that:

Substantive obligations in other international investment treaties and other trade agreements do not in themselves constitute 'treatment', and thus cannot give rise to a breach of this [MFN] Article, absent measures adopted or maintained by a Party pursuant to those obligations.

A similar clarification is missing in the TPP, a fact that might compel the TPP Members to adopt an authoritative interpretation in the future. Art. 9.5.3 TPP merely spells out that the MFN obligation does not extend to provisions on dispute resolution.

At large, to guarantee policy space is the very function of exception clauses. Therefore, the scope of these clauses is key, as well as the operation of the principle of proportionality thereunder. ${ }^{228}$ These are the parameters within which the negotiators have to make a decision: the broader the exceptions, the greater the autonomy of States. The more flexible the exceptions are designed, the less legal certainty prevails. It is sensible to model the exceptions on the tried and tested WTO exceptions, thus incorporating the wealth of WTO case law. But neither the TPP nor CETA remedy the problem that only particular policy objectives can justify an infringement.

In summary, two lessons can be learned for the negotiations of TTIP and RCEP, respectively: Firstly, the list of legitimate policy objectives that can justify a violation should not be exhaustive. Secondly, the exceptions should be applicable to the investment chapter as well. As to the first point, having a non-exhaustive list would make the development of mandatory requirements à la Cassis de Dijon superfluous. This would streamline the legal analysis. As to the second point, a broad exception clause that encompasses the investment chapter makes the discussion on ISDS less acute. ${ }^{229}$ Even the need for a tobacco carve-out along the lines of Art. 29.5 TPP, given that such a clause will always include health, would be less pressing.

As to the desirability of broad exceptions, pronouncements in both directions can be found. In Pope \& Talbot v. Canada, the tribunal noted that 'a blanket exception for regulatory

227 Cottier, 'Multilayered Governance, Pluralism, and Moral Conflict' 656.

228 See Riffel, 'Human Rights Protection in the Asia-Pacific: What Will Be the Role of the TPP?' 343-344, 347348.

${ }^{229}$ See, e.g., Art. 9.8 China-Australia FTA. 
measures would create a gaping loophole in international protections against expropriation. ${ }^{230}$ Contrariwise, the tribunals in SD Myers v. Canada and Lemire v. Ukraine referenced the 'high measure of deference that international law generally extends to the right of domestic authorities to regulate matters within their own borders.' ${ }^{231}$ The Award in Marvin Feldman v. Mexico ties in with that:

governments must be free to act in the broader public interest through protection of the environment ... Reasonable governmental regulation of this type cannot be achieved if any business that is adversely affected may seek compensation ... ${ }^{232}$

What seems to be clear is that the exceptions to investors' rights under customary international law (force majeure, necessity) are not sufficient to ensure the right balance between international protection of foreign investments and regulatory autonomy, as adjudicating bodies tend to interpret substantive rights and obligations (e.g., non-discrimination, FET) broadly and exceptions under customary international law narrowly. ${ }^{233}$ If States wanted to go one step further and deprive ISDS of its edge, while still maintaining the system, they could do so by limiting damages to the reliance interest.

${ }^{230}$ Pope \& Talbot Inc v. Government of Canada (Interim Award) (26 June 2000) 7 ICSID Rep 69, 99.

231 SD Myers v. Canada (First Partial Award) (13 November 2000) (UNCITRAL/NAFTA) 263; Lemire $v$. Ukraine (Decision on Jurisdiction and Liability) (14 January 2010) ICSID Case No ARB/06/18, 505.

${ }^{232}$ Marvin Feldman v. Mexico (Award) (16 December 2002) ICSID Case No ARB (AF)/99/1, 103.

${ }^{233}$ See, e.g., CMS Gas Transmission Company v Republic of Argentina (Award) (12 May 2005) ICSID Case No $\mathrm{ARB} / 01 / 8,317$, with respect to necessity in terms of Art. 25 Articles on State Responsibility. 